\title{
Socio-hydrologic modeling of the dynamics of cooperation in the transboundary Lancang-Mekong River
}

\author{
You Lu ${ }^{1}$, Fuqiang Tian ${ }^{1}$, Liying Guo ${ }^{1}$, Iolanda Borzì ${ }^{2}$, Rupesh Patil ${ }^{3}$, Jing Wei ${ }^{1}$, Dengfeng Liu ${ }^{4}$, Yongping Wei ${ }^{3}$, \\ David J. $\mathbf{Y u}^{5,6}$, and Murugesu Sivapalan ${ }^{7,8}$ \\ ${ }^{1}$ Department of Hydraulic Engineering, State Key Laboratory of Hydro-science and Engineering, \\ Tsinghua University, Beijing 100084, China \\ ${ }^{2}$ Department of Engineering, University of Messina, 98168 Messina, Italy \\ ${ }^{3}$ School of Earth and Environmental Sciences, University of Queensland, St. Lucia, QLD 4072, Australia \\ ${ }^{4}$ State Key Laboratory of Eco-hydraulics in Northwest Arid Region, Xi'an University of Technology, Xi' an 710048, China \\ ${ }^{5}$ Lyles School of Civil Engineering, Purdue University, West Lafayette, IN 47907, USA \\ ${ }^{6}$ Department of Political Science, Purdue University, West Lafayette, IN 47907, USA \\ ${ }^{7}$ Department of Geography and Geographic Information Science, University of Illinois at Urbana-Champaign, \\ Urbana, Illinois, 61801, USA \\ ${ }^{8}$ Department of Civil and Environmental Engineering, University of Illinois at Urbana-Champaign, \\ Urbana, Illinois, 61801, USA
}

Correspondence: Fuqiang Tian (tianfq@mail.tsinghua.edu.cn)

Received: 27 July 2020 - Discussion started: 10 August 2020

Revised: 3 January 2021 - Accepted: 2 March 2021 - Published: 9 April 2021

\begin{abstract}
The transboundary Lancang-Mekong River basin has experienced dynamics of cooperation over the past several decades, which is a common emergent response in transboundary coupled human-water systems. Downstream countries rely on the Mekong River for fisheries, agriculture, navigation and ecological services, while upstream countries have been constructing dams to generate hydropower. The dam construction and operation in upstream countries have changed the seasonality of streamflow in downstream countries, affecting their economic benefits. More recently, cooperation between upstream and downstream countries has been enhanced throughout the river basin. In this study, we introduce a quantitative socio-hydrological model to simulate hydrological processes, reservoir operations, economic benefits, policy feedbacks and therefore dynamics of cooperation within the Lancang-Mekong River basin. The model reproduces the observed dynamics of cooperation in the basin revealed by sentiment analysis of news articles. Hydrological variability such as droughts and human activities associated with reservoir operations affect dynamics of cooperation between the riparian countries, with importance attached to indirect political benefits of upstream playing an
\end{abstract}

important role in the enhancement of cooperation. In this way, our study generated understanding of emergent cooperation dynamics in this transboundary river basin, and the socio-hydrological model used here provides a useful new framework to investigate and improve transboundary water management elsewhere.

\section{Introduction}

Transboundary water management is an important and complex issue that has attracted much attention and efforts globally. Transboundary rivers refer to rivers shared by two or more countries (Wolf et al., 1999) or two or more states within individual countries. There are over 310 transboundary rivers spanning over 150 countries, covering more than $40 \%$ of the world's human population and land areas (UNEP, 2016; McCracken and Wolf, 2019). Rivers serve multiple functions that benefit human societies such as water supply, irrigation, fishery, navigation, hydropower generation and provision of numerous other ecosystem services. These functions can vary spatially within a river basin, and consequently 
societal preferences for water use may also differ in different locations, leading to possible disputes and conflicts between upstream and downstream uses. Under these circumstances, cooperation among the various stakeholders is critical for water security, food security, energy security, and ecosystem security in riparian countries or regions, which requires equitable and reciprocal benefit sharing for humans to realize the full potential of the services that rivers provide. Transboundary river cooperation could take different forms (Sadoff and Grey, 2005) and operate at different levels (Sadoff and Grey, 2002), such as information sharing for flood and drought mitigation, reservoir operations adapted to the needs of both upstream and downstream users, and joint ownership of water-related infrastructure.

Compared to water resources management in domestic river basins, management of transboundary rivers that cross national boundaries must deal with an additional complexity. The complexity arises from the structural challenge to cooperation that in such international river basins two or more countries must organize cooperation despite potential differences in preferences for water uses and locational asymmetries in terms of access to water. Under these circumstances, cooperation among stakeholders could be intertwined with other issues or is limited by riparian relations, compounded by institutional limitations (Wolf et al., 1999) and differing national economic and strategic interests. Even if a formal social contract (e.g., an international treaty) can be devised among stakeholders to institutionalize cooperation, enforcement of the contract remains another challenge (Petersen-Perlman et al., 2017). Because of the international nature of these contracts, there is usually no external body that can enforce the formal arrangements for cooperation in a binding way (Müller et al., 2017; Espey and Towfique, 2004). Despite the challenges in transboundary river cooperation, there are examples of successful cooperation in international rivers, including the Rhine river (Schultz, 2009), the Columbia River (Hamlet, 2003) and the Colorado River (Bernal and Solís, 2000). At the same time, there are also cases of cooperation failures, such as the Amu Darya and Syr Darya rivers (Micklin, 2004; Tian et al., 2019). Much scholarly attention has been directed towards understanding what leads to success or failure in cooperation in transboundary river management.

Researchers have spent considerable efforts to analyze and understand the aforementioned question through empirical research and modeling efforts (De Stefano et al., 2017; De Bruyne and Fischhendler, 2013; Bernauer et al., 2012; Beck et al., 2014). The International Water Events Database has collected cooperative and conflictive water interactions in transboundary river basins globally and provides useful data and frameworks for further statistical studies (De Stefano et al., 2010; Munia et al., 2016) and detailed investigations in specific basins (Feng et al., 2019). Statistical methods or case studies help to identify the broad factors affecting transboundary river cooperation, including natural conditions (e.g., hydrological scarcity and variability) (Dinar et al., 2010; Dinar, 2009), political relations (Zeitoun and Mirumachi, 2008), power dynamics (Zeitoun et al., 2011; Petersen-Perlman et al., 2017), institutional arrangements (Dinar, 2009), and the relative levels of social and economic development (Song and Whittington, 2004). Hydroeconomic models that involve hydrological simulation and benefit calculation and allocation through benefit maximization or game theory (Li et al., 2019) are also common methods used to analyze the human-water interactions in transboundary rivers. In particular, multi-agent simulation models consider each riparian country as an independent decision maker and focus on water allocation and benefit calculation (Teasley and McKinney, 2011; Giuliani and Castelletti, 2013). These modeling approaches have been applied to the Lancang-Mekong and the Nile river basins (Cai et al., 2003; Ringler and Cai, 2006; Arjoon et al., 2016; Basheer et al., 2018).

However, most of the model studies highlighted above have viewed cooperation in transboundary rivers in a static way and as an external variable, and whether to cooperate or not and/or the extent of cooperation are set as boundary conditions. In other words, they only capture the one-way effect, i.e., how cooperation takes effect on water resources and the economy, instead of considering the two-way feedbacks including how cooperation evolves driven by different factors. In reality, transboundary river cooperation is evolutionary in nature. For example, in the Colorado River basin shared by the USA and Mexico, industrialization and population growth have increased the stress on surface and groundwater resources and on water quality. Groundwater depletion and water pollution contributed to tension between the two countries from the 1940s. Following protracted negotiations, several treaties were signed and institutions built, with the result that the interactions between the USA and Mexico have now become more cooperative in recent years (Frisvold and Caswell, 2000). The approaches used in studies to date do not accommodate the dynamic co-evolutionary nature of transboundary cooperation and conflicts, as seen for example in the Colorado River basin, and are therefore not up to the task of seeking mechanistic explanations for the observed dynamics of cooperation in transboundary river basins.

In this study, we aim to address this knowledge gap by adopting a process-based, socio-hydrologic framework to represent transboundary cooperation in the LancangMekong River basin, which involves China, Myanmar, Laos, Thailand, Cambodia and Vietnam as riparian states. Using dynamic modeling to understand the mechanisms behind cooperative or conflictive actions of riparian countries, not only in a specific river basin, but also similarities and differences between basins, would help in elucidating key drivers that account for differences in the cooperation level and its dynamics over time. This is a first step in this direction. Increased mechanistic understanding will help increase the scope of cooperation and avoidance of conflict in the future and generate 
diverse benefits (Sadoff and Grey, 2002; Yu et al., 2019a). Enhanced cooperation could lead to harmony in humanwater relations generally and regionally, including equitable and sustainable use of water. Conversely, the continuation of conflicts could result in disordered water use, overexploitation (Tian et al., 2019) and overall loss of amenities.

In approaching this aim, it is critical to capture the twoway feedbacks between the social system and the transboundary river system. Human society and hydrological systems have become ever more tightly coupled, and in the long term, co-evolution of the resulting coupled sociohydrological system has been shown to result in emergent dynamics and unintended consequences (Sivapalan and Bloschl, 2015). Examples include decadal asymmetric dynamics of human water consumption in several large semiarid river basins in Asia (Tian et al., 2019) and the "pendulum swing" in agriculture water use and human development in both eastern and western Australia (Kandasamy et al., 2014). Socio-hydrology as a science explores the twoway feedbacks between human and water systems, which is necessary to understand and mimic observed emergent dynamics (Sivapalan and Bloschl, 2015). Driven by both natural and social forces, a transboundary river basin can also be viewed as a coupled socio-hydrological system, now with a distinct spatial (upstream-downstream) dynamics mediated by multiple riparian states. Observed patterns of cooperation and conflict in a transboundary basin can then be seen as a special case of emergent dynamics that results from interactions and feedbacks between the actions of water users or stakeholders in upstream and downstream riparian states and the interplay of associated hydrological, economic, social and geopolitical processes (Di Baldassarre et al., 2019). Historical patterns of the intensity or levels of cooperation between riparian states are key indicators that can be used as targets of socio-hydrologic models developed with the aim of generating mechanistic understanding of the co-evolutionary paths followed by transboundary river basin management.

In this study, we will present a socio-hydrological model developed to simulate the dynamics of conflict and cooperation in transboundary river systems, as well as its application to the Lancang-Mekong River basin, which to the best of our knowledge is the first model to include the evolutionary transboundary river cooperation as an internal variable, and couple the driven processes including hydrological variability, dam construction and political benefits. It differs from extant models by considering transboundary river cooperation internally, dynamically and quantitatively. To attain the goal, we propose a novel quantification of cooperation level and political benefits and conduct sentiment analysis of newspaper articles to validate the simulation of cooperation in the Lancang-Mekong River basin. The socio-hydrological model developed is used to mimic the mechanisms of cooperation in this basin in a way to gain basic understanding that may be transferred to transboundary river basins elsewhere.
The remainder of the paper is organized as follows. In Sect. 2, we will introduce the study area and the history of observed dynamics of cooperation and conflict. Section 3 will present the rationale and details of the socio-hydrological model, including the various modules and governing equations describing the various subsystems, as well as how they are coupled in a way to capture the dynamics of cooperation and conflict. Section 4 presents the simulation results and a discussion and interpretation of the results, followed by, in Sect. 5, a summary of the main conclusions and the understanding and insights gained from the study.

\section{Study area and historical timeline of cooperation and conflict dynamics}

The Lancang-Mekong River is an important transboundary river located in Southeast Asia. As shown in Fig. 1, it originates from the Tibetan Plateau in China, and over its entire length of $4900 \mathrm{~km}$ it passes through Myanmar, Laos, Thailand, Cambodia and Vietnam (Wang et al., 2017). The Lancang-Mekong River basin drains an area of $812400 \mathrm{~km}^{2}$ and supports the water needs and livelihoods of over 65 million people (Ringler and Cai, 2006; MRC, 2018; You et al., 2014). The annual average discharge of the LancangMekong River flowing into the South China Sea is close to 475 billion $\mathrm{m}^{3} \mathrm{yr}^{-1}$ (Campbell, 2016). The drainage area of the upstream part, i.e., the Lancang River basin in China, is $195000 \mathrm{~km}^{2}$, which accounts for $24 \%$ of the whole basin area. The Mekong River basin in Myanmar, Laos, Thailand, Cambodia and Vietnam covers an area of around $600000 \mathrm{~km}^{2}$ (Li et al., 2017).

Starting from a relatively undeveloped basin in the 1950s, the Lancang-Mekong River basin has experienced rapid economic growth in recent decades (MRC, 2010). Although they all have many shared interests, different riparian countries within the Lancang-Mekong River basin benefit from different river functions. For example, while all riparian countries have the need to protect themselves from the negative impacts of floods and droughts and ensure the sustainability of riverine ecosystem, the upper riparian states of China and Laos have constructed and plan to construct many dams, mainly for hydropower generation (Keskinen et al., 2012). For the downstream states of Thailand, Cambodia, and Vietnam, agriculture and fishery are the main uses of the Mekong River. Irrigated agriculture is a major water consumer in the basin (MRC, 2018), and rice is the main staple crop (Campbell, 2016). In the lower Mekong region, especially in Cambodia and Vietnam, fishery not only employs a large number of people, but also sustains their protein demands (Campbell, 2016).

As an important and geopolitically sensitive region (Campbell, 2016), the Lancang-Mekong River basin has experienced both conflict and cooperation since the end of World War II under the impacts of changing geopolitical re- 


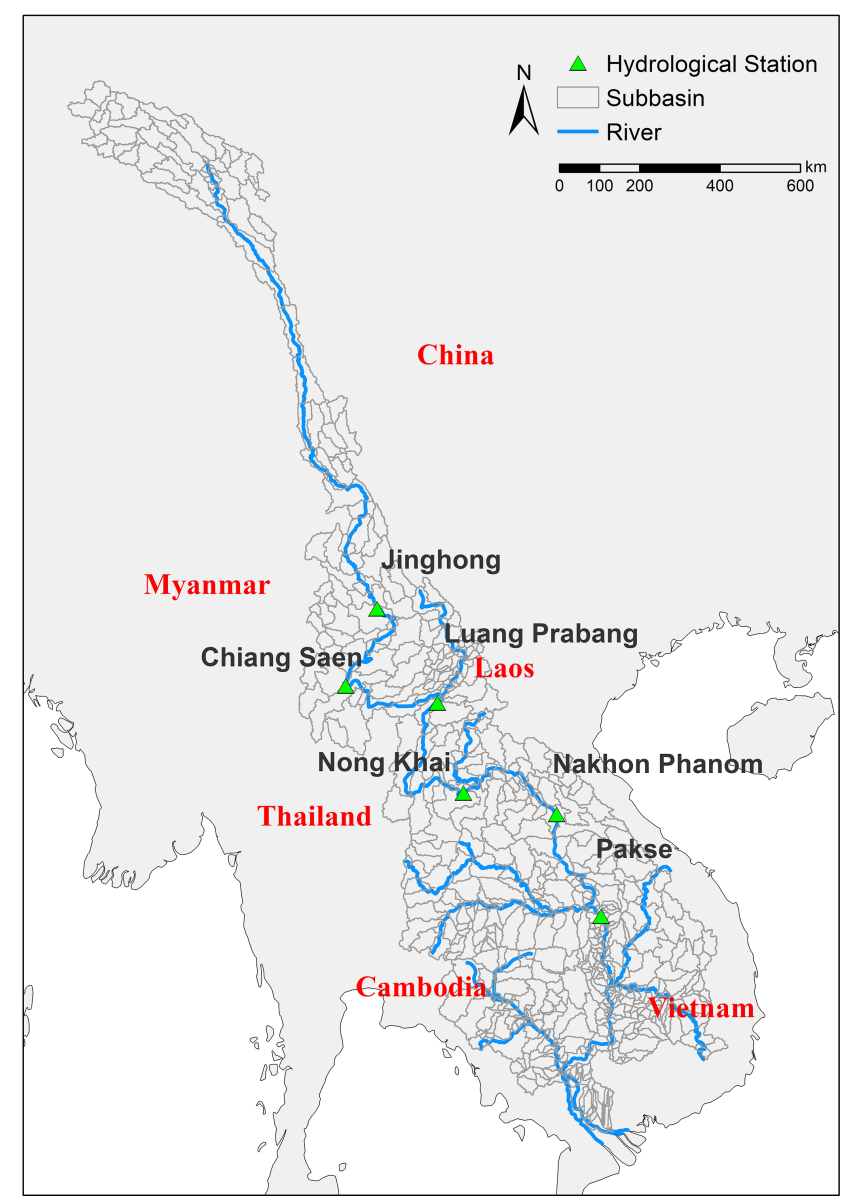

Figure 1. Map of the Lancang-Mekong River basin, subbasin division and hydrological stations.

lationships, hydrological dynamics and socioeconomic conditions. With the sponsorship of the United Nations agency ECAFE, the Committee for Coordination of Investigations of the Lower Mekong Basin was initiated in 1957, and early efforts included the setting up of comprehensive hydrological observations and the setting up of regional plans for hydropower, flood control and irrigation (Campbell, 2016). However, because of the withdrawal of Cambodia in 1977 due to political reasons, Thailand, Laos and Vietnam initiated the Interim Committee for Coordination of Investigations of the Lower Mekong Basin, which took limited efforts towards regional cooperation. Until 1995, the four countries of the lower Mekong were part of the Agreement on the Cooperation for the Sustainable Development of the Mekong River Basin, through which they established the Mekong River Commission (MRC). MRC was designed to enhance cooperation on water utilization and management, socioeconomic development, and ecosystem conservation (MRC, 1995). Although China signed an agreement on the provision of hydrological information on the Lancang-Mekong River in 2002, the efforts of MRC were limited due to the absence of the upstream states, namely China and Myanmar. Finally, the Lancang-Mekong Cooperation Mechanism (LMC) was initiated in 2016 to include all of the six riparian countries and thus enhance more comprehensive cooperation (Feng et al., 2019).

Specifically, cooperation in the Lancang-Mekong River in the 21st century has been in the spotlight because of rapid changes in climatic and hydrological conditions, intensified human activity, and geopolitical sensitivity of the region. Dam construction principally in the two upstream countries, China and Laos, has continued over three decades. Since 2010, large hydropower plants have been commissioned on the mainstream of the Lancang-Mekong River (Han et al., 2019). Reservoir operations in the upstream increase dry-season runoff and reduce runoff peaks during the flood season (Hoanh et al., 2010). The resulting changes in river flow were strongest in the upper Chiang Saen station in Thailand and less noticeable in the lower station Kratié in Cambodia (MRC, 2018). The resulting change in seasonality of river flows has a significant impact on the benefits of different water uses (Pokhrel et al., 2018), for example, wetland ecosystem services (Dudgeon, 2000) in Vietnam, and fish capture in the largest freshwater lake in Southeast Asia, Tonlé Sap Lake (Kite, 2001) located in Cambodia. Correspondingly, due to the effects of upstream dam operations for hydropower generation, the downstream countries have faced concerns about benefit losses. Here the loss indicates deviation from their maximum expected benefit (Kahneman and Tversky, 1979). To obtain indirect political benefits, which are described as "diplomatic returns" in Yu et al. (2019b), the upstream country of China has worked to change flow regulations of their reservoirs to satisfy the demands of the downstream countries and achieve regional cooperation. One example of this was the emergency water release from China in 2016 to alleviate the effects of a severe drought in the lower Mekong basin (Yu et al., 2019b). This change in hydropower dam regulations in upstream countries can be regarded as an example of a cooperative response.

Figure 2 summarizes the hydrological and anthropogenic events in the Lancang-Mekong River basin. The upstream countries of China and Laos have constructed or planned to construct dams on the mainstream of the Lancang-Mekong River. Two major reservoirs on the mainstream, Xiaowan and Nuozhadu, went into production in 2010 and 2012 respectively. The filling and operation of these reservoirs caused the alteration of hydrological regimes in the downstream countries, i.e., increase in runoff in the dry season and reduction in the flood season. Economic losses compared to expected benefits caused by the change in hydrological seasonality and natural droughts led to concerns raised by downstream countries and tension and conflict. However, cooperation has been enhanced in recent years, exemplified by some cooperative actions of the upstream country of China, such as the emergency water release during a period of drought. We will use the socio-hydrological model to simulate these water-related 


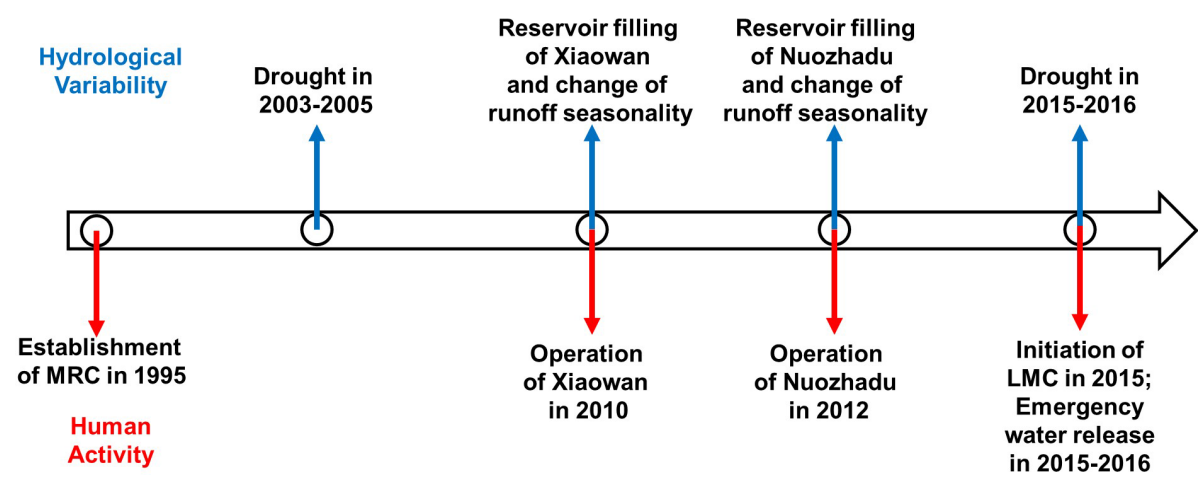

Figure 2. Timeline of hydrological and anthropogenic events in the Lancang-Mekong River basin.

events and the cooperation dynamics and provide mechanistic explanations based on socio-hydrologic interpretation of the emergent dynamics.

\section{Socio-hydrological model}

We developed a transboundary river cooperation sociohydrological model (TCSH model) to simulate the dynamics of cooperation and conflict observed in the LancangMekong River basin. The causal loop presented in Fig. 3 introduces the main components of the model. It simulates the change in river flow seasonality caused by reservoir operations, which causes benefit loss compared to expected benefits to downstream countries in different sectors. The loss compared to expected benefits leads to demands by the downstream countries for more cooperation from upstream countries, to which the upstream countries respond with changes to their reservoir operations. The modeled levels of cooperation, and the resulting changes to reservoir operations, are determined by a balance between hydropower losses and indirect gain of geopolitical benefits by the upstream countries.

As seen in Fig. 3, the socio-hydrological model couples four main parts, i.e., hydrological simulation, reservoir operation, economic benefit calculation and policy feedback. A distributed catchment hydrological model is used to model natural streamflow inputs to the dams and is calibrated using observations at several stations along the Lancang-Mekong River. With available reservoir information, the reservoir operation module simulates two basic scenarios, i.e., maximizing upstream benefits versus maximizing downstream benefits. The results of these two operational scenarios are weight averaged to calculate actual water releases and reservoir storage. The economic benefit calculation module estimates the economic benefits for both upstream and downstream countries covering hydropower, irrigation and fishery sectors based on outcomes of the hydrological simulation and reservoir operation modules. Based on the estimation of economic benefits, the fourth module simulates the policy feed-

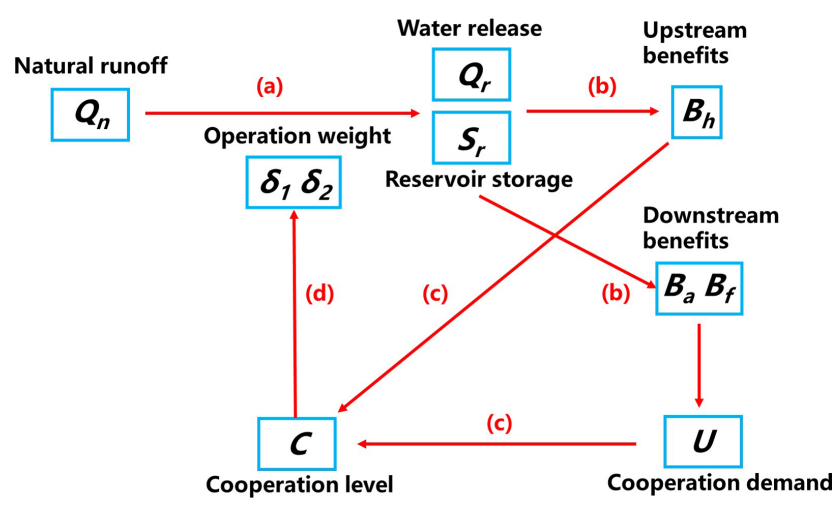

Figure 3. Framework of transboundary river socio-hydrological model. (a) Reservoir operations with regulation rules, constraints and operation weights. (b) Economic benefit calculations in hydropower, agriculture and fishery. (c) Cooperation calculations based on economic benefits. (d) Cooperation feedbacks to change operation weights, $\delta_{2}=C$.

backs through two key variables, i.e., cooperation demand of downstream countries and cooperation level of upstream countries. Outcomes of sentiment analysis of newspaper articles are used to evaluate the modeled cooperation demand. The calculation step length of the model is 1 month. Each of these components of the model is discussed in detail in the following sections.

\subsection{Hydrological simulation}

We use the distributed hydrological model THREW (Tsinghua Representative Elementary Watershed) to simulate natural runoff of mainstream and tributaries without impacts of reservoir operations, i.e., $Q_{\mathrm{n}}$ in Fig. 3. The THREW model has been applied to many river basins successfully, including rivers derived from mountainous areas and consisting of snow and glacier melt, as well as large-scale basins (Tian et al., 2006, 2008; Li et al., 2012; Mou et al., 2008). Based on the Representative Elementary Watershed (REW) approach (Reggiani et al., 1998), the THREW model uses the REW 
as the sub-catchment unit for hydrological simulations ( $\mathrm{He}$ et al., 2015). The main runoff generation processes include surface runoff, groundwater flow, and snow and glacier melt.

In this study, we divide the Lancang-Mekong basin into 651 REWs on the basis of DEM data, as shown in Fig. 1. The precipitation data are retrieved from Tropical Rainfall Measuring Mission (TRMM) data of 1998-2018. The accuracy of TRMM data for hydrological simulation in this region has been proven successfully (MRC, 2018). Thirty-two meteorological stations distributed around the whole basin provide meteorological inputs, including temperature, wind speed, humidity and radiation to calculate potential evapotranspiration based on the Penman-Monteith equation. Soil data are extracted from the FAO world soil database, and leaf area index (LAI), normalized difference vegetation index (NDVI) and snow are obtained from MODIS data. Daily runoff observations of six stations on the mainstream of the Lancang-Mekong River include data of Jinghong (19982013), Chiang Saen (1998-2015), Luang Prabang (19982015), Nong Khai (1998-2007), Nakhon Phanom (19982015) and Pakse (1998-2006).

As the hydrological model is used to provide simulations of natural runoff without the impacts of water withdrawal and reservoir operations, we use the runoff data in the period before large reservoir construction for parameter calibration, i.e., runoff data of the period of 1998-2009. The parameters are calibrated separately and in a spatially distributed manner. Specifically, the year of 1998 is used as a warm-up period, 1999-2004 as the calibration period and 2005-2009 is set as the validation period. The simulated runoff of 2000 2018 is used as natural flow of mainstream and tributaries $Q_{\mathrm{n}}$ before the impacts of human activities.

\subsection{Reservoir operation}

The largest two reservoirs in China with seasonal runoff regulation capacity (Yu et al., 2019b), namely Xiaowan and Nuozhadu, went into operation in 2010 and 2012 respectively. The basic information of Xiaowan and Nuozhadu including the total reservoir storage $S_{\text {total }}$, dead reservoir storage $S_{\text {dead }}$, and flood limited storage $S_{\text {flood }}$ are listed in Table 1. Laos has aimed to be the "battery of Southeast Asia" (Stone, 2016) and started hydroelectric dam construction on the mainstream of the Mekong River in line with this ambition. Before that, Laos constructed many dams on its tributaries, which also impact the streamflow regimes of the Mekong River. According to MRC (2018), the expected live storage of reservoirs in Laos will ultimately reach 24257 MCM (million cubic meters). In order to couple the reservoir operation module with the other modules, we need to simplify the cascade of reservoirs in both China and Laos so that the optimization processes in reservoir operation module and benefit calculation module could be computed. With the total storage of the Xiaowan and Nuozhadu reservoirs accounting for $90 \%$ of the total storage of the largest
Table 1. Reservoir information of Xiaowan and Nuozhadu.

\begin{tabular}{lcccr}
\hline Reservoir & $\begin{array}{c}\text { Commissioned } \\
\text { year }\end{array}$ & $\begin{array}{c}\text { Total } \\
\text { reservoir } \\
\text { storage } \\
(\mathrm{MCM})\end{array}$ & $\begin{array}{c}\text { Flood } \\
\text { limited } \\
\text { storage } \\
(\mathrm{MCM})\end{array}$ & $\begin{array}{r}\text { Dead } \\
\text { reservoir } \\
\text { storage } \\
(\mathrm{MCM})\end{array}$ \\
\hline Xiaowan & 2010 & 15300 & 13104 & 5946 \\
Nuozhadu & 2012 & 21749 & 19344 & 10414 \\
\hline
\end{tabular}

six reservoirs (Han et al., 2019), the cascade of reservoirs within China is simplified and approximated in this study by the two reservoirs. For the reservoirs in Laos, since reservoirs on the mainstream have not been commissioned before 2019, only the completed tributary reservoirs are considered and aggregated by one virtual reservoir in the upper reaches, including some reservoir storage located in the relatively lower reaches in Laos (Li et al., 2019; WLE, 2018). The storage of the virtual Laos reservoir equals the sum of all Laos reservoir storage, and its hydropower generation is calibrated against the statistical data of the sum of hydropower generations in Laos. In the model, the virtual Laos reservoir is assumed to have live storage from $5074 \mathrm{MCM}$ in 2000 to $21066 \mathrm{MCM}$ in 2018, which was linearly interpolated over this time period and represents continuous dam construction in Laos.

Overall, these simplifications through lumping the effects of many reservoirs are deemed reasonable for the purpose of this study, because three reservoirs (Xiaowan and Nuozhadu in China and the aggregated Laos reservoir) shown in Fig. 4 capture most of the effects of reservoirs within the entire river basin and closely resemble the actual hydropower generation. As shown in Fig. 4, the river system and its water diversion configuration are also simplified, where $T_{1}$ and $T_{2}$ to $T_{6}$ indicate natural runoff of upstream and tributaries, and $W_{1}-W_{3}$ are the water withdrawals for irrigation in Thailand, Cambodia and Vietnam. For each node, runoff flowing to the next node is calculated by the water balance equation, e.g., for Thailand,

$Q_{7}=Q_{6}+T_{5}-W_{1}$,

where $Q_{7}$ is runoff flowing to Thailand from the upstream node, Laos; $T_{5}$ is inflow from tributaries in Thailand; $W_{1}$ is irrigation withdrawal in Thailand; and $Q_{7}$ is runoff flowing to the downstream node, Cambodia.

For the operation of constructed dams, we consider two basic scenarios. The first scenario is the self-interested scenario (non-cooperation scenario, abbreviated by NC), in which the upstream countries, China and Laos, operate the dams considering only their own hydropower benefits. Under this scenario, dams keep at their total storage $S_{\text {total }}$ during the dry season (November to May) and their flood limited storage $S_{\text {flood }}$ in the flood season (June to October). If the actual storage of the $t-1$ period $S_{\mathrm{r}, t-1}$ is less than these two values, the reservoir will store water to reach the amount; otherwise, 


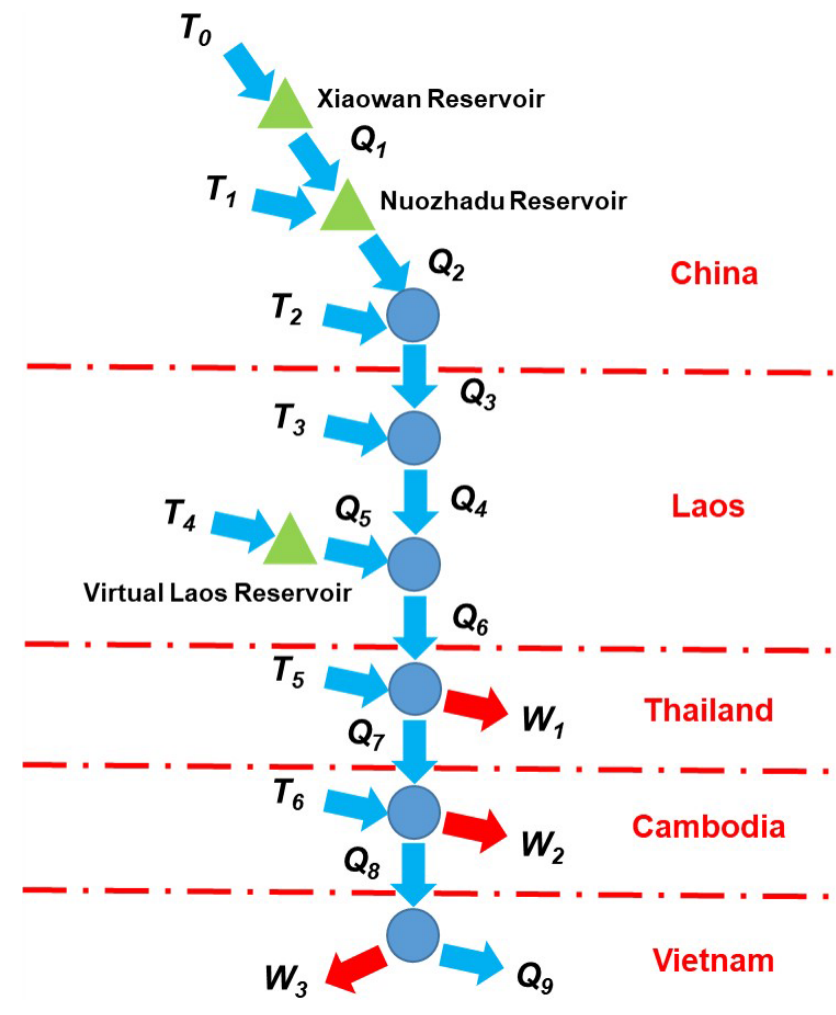

Figure 4. Framework of simplified water system in the LancangMekong River basin.

the reservoir will release water. There are also constraints on the minimum ecological release flow $Q_{\text {eco }}$ to satisfy the requirements of ecosystem and navigation. Actual water release under the self-interested scenario $Q_{\mathrm{r}, \mathrm{NC}}$ is calculated using Equations (2) and (3). The actual storage of the next month $S_{\mathrm{r}, t}$ is calculated based on the water balance equation. With the calculated water release under the self-interested scenario $Q_{\mathrm{r}, \mathrm{NC}}$, the total benefits of the three downstream countries will be optimized through water allocation among them.

$$
\begin{gathered}
Q_{\mathrm{r}, t}=\max \left\{S_{\mathrm{r}, t-1}+Q_{\mathrm{in}, t}-S_{\mathrm{total}}, 0, Q_{\mathrm{eco}}\right\}, \\
\quad t=1,2,3,4,5,11,12 \\
Q_{\mathrm{r}, t}=\max \left\{S_{\mathrm{r}, t-1}+Q_{\mathrm{in}, t}-S_{\text {flood }}, 0, Q_{\mathrm{eco}}\right\}, \\
\quad t=6,7,8,9,10
\end{gathered}
$$

The second scenario is the altruistic scenario (fullcooperation, abbreviated by FC), where the upstream countries operate the dams to accommodate downstream water demands and maximize the benefits of downstream countries. The calculation of the benefits to downstream countries will be introduced in Sect. 3.3. Under this scenario, the constraints contain maximum storage during dry season, maximum storage during flood season, minimum storage of dead storage and minimum ecological release flow. Then the processed results of actual water release $Q_{\mathrm{r}, \mathrm{FC}}$ will be used to calculate actual reservoir storage $S_{\mathrm{r}}$ based on the water balance equation. In this study, neither the self-interested scenario nor the altruistic scenario considers hedging rules in reservoir operation, although this is an extension that could be considered in further extensions of this study.

As shown in Fig. 3, with the calculated water release under the self-interested scenario $Q_{\mathrm{r}, \mathrm{NC}}$ and that under the altruistic scenario $Q_{\mathrm{r}, \mathrm{FC}}$, we obtain the weighted average scenario (WA scenario) and final actual water release $Q_{\mathrm{r}}$ by calculating their weighted average.

$Q_{\mathrm{r}}=Q_{\mathrm{r}, \mathrm{NC}} \times \delta_{1}+Q_{\mathrm{r}, \mathrm{FC}} \times \delta_{2}$,

where $\delta_{1}+\delta_{2}=1$, and $\delta_{2}$ is calculated using the cooperation equations while $\delta_{1}$ is calculated as the residual $1-\delta_{2}$, which will be introduced in Sect. 3.4. Here $\delta_{2}$ reflects the extent to which the operating rules are adjusted to accommodate downstream water demands. It should be noted that the calculated $Q_{\text {r }}$ by Eq. (4) is revised if it violates the constraints of maximum storage during dry and flood seasons, minimum storage of dead storage, and minimum ecological release flow. The final actual reservoir storage $S_{\mathrm{r}}$ is used for hydropower benefit calculation, and the calculated $Q_{\mathrm{r}}$ is used to optimize the total benefits of the three downstream countries.

\subsection{Economic benefit calculation}

In this study, we consider the hydropower benefits $B_{\mathrm{h}}$ of China and Laos, as well as agriculture benefits $B_{\mathrm{a}}$ and fishery benefits $B_{\mathrm{f}}$ of Thailand, Cambodia and Vietnam. The hydropower benefit calculations of China and Laos are based on the water release $Q_{\mathrm{r}}$ and reservoir storage $S_{\mathrm{r}}$, as shown in Eq. (5).

$B_{\mathrm{h}}=p_{\mathrm{h}} \times 9.81 \times Q_{\mathrm{r}} \times \Delta h \times \eta$,

where $p_{\mathrm{h}}$ is the electricity price extracted from MRC (2018), $Q_{\mathrm{r}}$ is the monthly water release from the reservoir, $\Delta h$ is the water head difference between the upstream and downstream which is related to the actual storage $S_{\mathrm{r}}$, and $\eta$ is hydropower generation efficiency which is calibrated against the annual power generation data.

Here agriculture benefits $B_{\mathrm{a}}$ only include irrigated rice without consideration of rain-fed crop production. Agricultural water withdrawals dominate water consumption in the downstream countries, and rice is the staple crop in this area. In this study, we use the FAO 33 crop water production function to calculate crop yields and irrigation benefits (Doorenbos and Kassam, 1979).

$$
\begin{aligned}
& B_{\mathrm{a}}=p_{\mathrm{a}} \times Y_{\mathrm{a}} \times A, \\
& \left(1-\frac{Y_{\mathrm{a}}}{Y_{\mathrm{m}}}\right)=K_{\mathrm{y}} \times\left(1-\frac{E_{\mathrm{A}}}{E_{\mathrm{P}}}\right),
\end{aligned}
$$

where $p_{\mathrm{a}}$ is price of rice and retrieved from statistical data (MRC, 2018), $A$ is the rice irrigation area, and $Y_{\mathrm{a}}$ and $Y_{\mathrm{m}}$ are 
Table 2. Irrigated agriculture information of Thailand, Cambodia and Vietnam.

\begin{tabular}{lrrrl}
\hline & Thailand & Cambodia & Vietnam & Data source \\
\hline Rice price (USD t & & & \\
Irrigated area (million ha) & 243.8 & 267.6 & 248.0 & MRC (2018) \\
Rice yield (tha ${ }^{-1}$ ) & 1.425 & 0.505 & 1.921 & Cramb (2020) \\
Irrigation withdrawal (MCM) & 3.78 & 4.38 & 5.72 & MRC (2018) \\
\hline
\end{tabular}

actual and maximum crop yields respectively. $K_{\mathrm{y}}$ is the crop yield response factor, and $E_{\mathrm{A}}$ and $E_{\mathrm{P}}$ are actual and potential evapotranspiration respectively. The information on the price of rice, irrigation area, rice yield, and irrigation withdrawal of Thailand, Cambodia and Vietnam is listed in Table 2. $Y_{\mathrm{m}}$ is set as $8.5 \mathrm{tha}^{-1}$ for all three countries (FAO, 2004). $E_{\mathrm{A}}$ and $E_{\mathrm{P}}$ are calculated based on potential evapotranspiration and irrigation amount, and the detailed methods could be found in Allen et al. (1998) and Kaboosi and Kaveh (2012).

Fishery is one of the dominant environmental water uses in the lower Lancang-Mekong River basin, but it is difficult to quantify fishery benefits. In general, comprehensive fisheries models have many required inputs to calculate fishery benefits, such as mortality, recruitment and fishing efforts (Baran and Cain, 2001). There are many studies focusing on the simulations of fishery benefits through their relationships with water level (Hortle et al., 2005) and flooded areas (Burbano et al., 2020). It is difficult to couple complex fishery models to our model, and there has not been any standard function for fishery benefits up till now. Here, for simplicity, we only consider capture fishery benefits and do not include aquaculture benefits, since the latter is not significantly impacted by hydropower operation. Based on literature review, an increasing function of runoff with decreasing marginal increase was adopted to calculate capture fishery benefits, which is simple but effective in the Mekong basin (Ringler, 2001; Ringler and Cai, 2006).

$d=\arctan \left(\frac{Q-Q_{\min }}{Q_{\max }}\right) \times\left(1-b \times\left(\frac{Q-Q_{\min }}{Q_{\max }}-c\right)^{2}\right)$,

$B_{\mathrm{f}}=p_{\mathrm{f}} \times d-F_{\text {cost }}$,

where $d$ is the fishery production related to actual discharge $Q$, minimum discharge $Q_{\min }$, maximum discharge $Q_{\max }$, and two parameters $b$ and $c$. In Eq. (9) to calculate fishery benefit $B_{\mathrm{f}}, p_{\mathrm{f}}$ is the fishery price extracted from statistical data (MRC, 2018), and $F_{\text {cost }}$ is the fixed fishery cost. Overall, fishery benefits for downstream countries are related to actual runoff, maximum runoff and minimum runoff. As shown in Fig. $4, Q_{7}-Q_{9}$ are used as actual runoff to calculate fishery benefits for Thailand, Cambodia and Vietnam respectively.

\subsection{Policy feedback}

Cooperation demands $U$ of downstream countries arise from economic losses compared to expected benefits, and the upstream countries take cooperative action to obtain indirect political benefits, although this might reduce their hydropower generation benefits. It is always difficult to quantify cooperation demand and cooperation level. As a first attempt, in this study we only consider change in operation rules of reservoirs as cooperative action and define the cooperation level $C$ of upstream countries as the weight assigned to the operation rules to maximize downstream benefits when upstream countries operate their reservoirs, i.e., $\delta_{2}$ in Sect. 3.2. When the cooperation level $C=1$, upstream countries operate dams to maximize the downstream benefits, i.e., the altruistic scenario. If $C=0$, upstream countries will follow operation rules given by Eqs. (2) and (3), which are consistent with the self-interested scenario.

Following the assumption that cooperation demand is increased due to economic losses compared to the reference level, larger economic losses will cause greater community concerns and thus increase cooperation demands. According to the theory of reference dependence, humans evaluate gains and losses relative to a reference point (Schmidt, 2003), and the reference point could be the status quo (Tversky and Kahneman, 1991) or the level of aspiration (Siegel, 1957). Here we value the losses relative to the expected maximum benefits of sectors $B_{\text {amax }}$ and $B_{\mathrm{fmax}}$, i.e., as the differences between expected maximum benefits and actual benefits. As shown in Eq. (10), we assume that the cooperation demand is proportional to economic losses, while the sensitivity of each economic sector is distinct.

$U=\varepsilon_{\mathrm{a}} \times \frac{B_{\mathrm{amax}}-B_{\mathrm{a}}}{B_{\mathrm{amax}}}+\varepsilon_{\mathrm{f}} \times \frac{B_{\mathrm{fmax}}-B_{\mathrm{f}}}{B_{\mathrm{fmax}}}$,

where $\varepsilon_{\mathrm{a}}$ and $\varepsilon_{\mathrm{f}}$ are the sensitivity of agriculture loss and fishery loss. The sensitivities indicate the importance of each sector to the overall lower basin economy, and larger sensitivity means that downstream countries are more sensitive to the benefit change in the sector, and the unit sector loss could lead to more severe negative impacts. In this model we assigned both $\varepsilon_{\mathrm{a}}$ and $\varepsilon_{\mathrm{f}}$ as 0.5 so that the agriculture and fishery losses are treated equally. The expected maximum benefits $B_{\text {amax }}$ and $B_{\text {fmax }}$ are used for normalization.

For the cooperation level of upstream countries, we use a logit dynamics model (McFadden, 1981; Hofbauer and Sig- 
mund, 2003) taken from environmental economics practice. This model is used to relate economic benefits with the probability of cooperation. It has been widely used and proven effective to relate natural system dynamics with cooperation dynamics, e.g., the simulations of cooperation on pollution control among stakeholders, who respond to the behaviors of other stakeholders and their own benefits (Iwasa et al., 2007; Suzuki and Iwasa, 2009a, b). In the logit dynamics model, the probability of cooperation $P_{\mathrm{r}}$ could be calculated as follows:

$P_{\mathrm{r}}=\frac{e^{\beta \times B_{\mathrm{C}}}}{e^{\beta \times B_{\mathrm{C}}}+e^{\beta \times B_{\mathrm{N}}}}$,

where $\beta$ is a shape parameter, $B_{\mathrm{C}}$ is the benefit of cooperation and $B_{\mathrm{N}}$ is the benefit without cooperation.

Similarly, for upstream countries, if they choose not to cooperate, their benefit $B_{\mathrm{N}}$ will be hydropower generation benefits under self-interested scenario $B_{\mathrm{h}, \mathrm{NC}}$ and low indirect political benefit $B_{\mathrm{p}, \mathrm{NC}}$. If they choose to cooperate, besides the hydropower benefits under the altruistic scenario $B_{\mathrm{h}, \mathrm{FC}}$, the upstream country will gain higher indirect political benefits $B_{\mathrm{p}, \mathrm{FC}}$. Here we define the political benefit $B_{\mathrm{p}}$ as the benefit from avoidance of conflicts (Sadoff and Grey, 2002) and proportional to cooperation demand $U$ and a political factor $P$ as shown in Eq. (12). When the cooperation demand $U$ is high, and the cost due to dissatisfaction among downstream countries and potential conflicts is high, the political benefit $B_{\mathrm{p}}$ will be low. If the upstream country values the political relations with downstream countries and regards diplomatic benefits as important, as China has demonstrated in recent years, the value of political factor $P$ will be higher, and the cooperation demand $U$ will play a more important role in decision making. The equation to calculate the actual cooperation level $C$ for upstream is as described in Eq. (13).

$$
\begin{aligned}
& B_{\mathrm{p}}=-U \times P, \\
& \frac{\mathrm{d} C}{\mathrm{~d} t}=s \times\left[\frac{e^{\beta \times\left(\frac{B_{\mathrm{h}, \mathrm{FC}}}{B_{\mathrm{h} \max }}-U_{\mathrm{FC}} \times P\right)}}{e^{\beta \times\left(\frac{B_{\mathrm{h}, \mathrm{FC}}}{B_{\mathrm{h} \max }}-U_{\mathrm{FC}} \times P\right)}+e^{\beta \times\left(\frac{B_{\mathrm{h}, \mathrm{NC}}}{B_{\mathrm{h} \max }}-U_{\mathrm{NC}} \times P\right)}}-C\right],
\end{aligned}
$$

where $s$ is the responsive change rate reflecting the response speed of upstream countries, and $\frac{\mathrm{d} C}{\mathrm{~d} t}$ indicates the change in cooperation level compared to the last period. $B_{\mathrm{h}, \mathrm{FC}}$ and $B_{\mathrm{h}, \mathrm{NC}}$ are calculated on the basis of water release and reservoir storage under the altruistic scenario and self-interested scenario respectively by Eq. (5). Overall, cooperation levels $C$ are related to downstream cooperation demand $U$, political factor $P$ reflecting how much upstream countries value the indirect political benefits that can be gained from downstream countries, upstream benefits when cooperating or not $-B_{\mathrm{h}, \mathrm{FC}}$ and $B_{\mathrm{h}, \mathrm{NC}}$, and the responsive change rate $s$. Compared to Laos, China regards the geopolitical value and diplomatic relations as more important (Urban et al., 2018). Therefore, the political factor $P$ values of China and Laos are set as 2 and 1 respectively, while the change rate $s$ is set
Table 3. Critical parameters and values for uncertainty analysis.

\begin{tabular}{llrr}
\hline Denotation & Parameter & Value & $\begin{array}{r}\text { Alternative } \\
\text { value }\end{array}$ \\
\hline$\varepsilon_{\mathrm{a}}$ & sensitivity of agriculture loss & 0.5 & $0.4,0.6$ \\
$\varepsilon_{\mathrm{f}}$ & sensitivity of fishery loss & 0.5 & $0.4,0.6$ \\
$P_{\mathrm{c}}$ & China political factor & 2 & $1.5,2.5$ \\
$P_{1}$ & Laos political factor & 1 & $0.8,1.2$ \\
$s$ & responsive change rate & 0.5 & $0.4,0.6$ \\
$\beta$ & shape parameter & 1.5 & 1,2 \\
\hline
\end{tabular}

as 0.5. As mentioned before, the cooperation level $C$ equals the weight $\delta_{2}$, so the cooperation demand and cooperation level will affect reservoir regulations, and in this way it will drive the co-evolution of the coupled transboundary sociohydrological system. Parameters in policy feedback module assigned here could be adjusted so that the simulated downstream cooperation demands are consistent with the sentiment analysis results, which will be explained in Sect. 3.5.

The parameterization of the model could lead to uncertainty of simulations. In order to analyze the uncertainty of simulated cooperation demand caused by parameters, we choose six critical parameters shown in Table 3. Besides the values used in simulations, we choose two alternative values for each parameter and simulate cooperation demand of downstream under each parameter combination. For each value of one parameter, there are 243 simulations with the other five parameters unfixed, which are used for uncertainty analysis.

\subsection{Sentiment analysis and validation}

Empirical observational data are needed to evaluate the simulation of policy feedbacks. It is difficult to measure cooperation demand, particularly the cooperation among countries on a specific item, i.e., reservoir operation and water resources management. Sentiment analysis is an emerging tool to quantify social data, which exploits the denotation of words and assigns sentimental value to text strings by an algorithm (Bravo-Marquez et al., 2014; Abdul et al., 2019). It has already been used to provide information of the attitudes of Chinese citizens towards dam construction (Jiang et al., 2016). Newspaper articles could reflect public opinion on issues of interest to the community, which have been used in previous socio-hydrologic studies to monitor the evolution of environmental awareness vis-à-vis economic livelihood (Wei et al., 2017). In this study, we use the sentiment analysis of newspaper articles in downstream countries in the LancangMekong River basin to reflect the changes in cooperation demands of downstream countries. The sentiment analysis is used to demonstrate the validity of the socio-hydrological model. 
The detailed steps of sentiment analysis of newspaper articles and its application in the Lancang-Mekong River have been introduced in Wei et al. (2020), and we will introduce the general steps briefly as follows. We used the LexisNexis database to extract relevant information in English newspapers (Weaver and Bimber, 2008), sorted the data manually and conducted sentiment analysis. Although the English newspapers have the potential to miss some information when compared to local language newspapers, they are considered a reference to the government's foreign policy, and they can reflect national interests and political responses that riparian countries want to deliver to the international public (Wei et al., 2020). Firstly, key words for search (e.g., Mekong, water, dam) and search limitations (e.g., location of publisher) are set for this study, and data are retrieved from the news database. Secondly, manual data sorting was used to remove duplicates and irrelevant news. Thirdly, the sorted data were analyzed through coding to get the sentiment of each piece of news and then corrected manually. Finally, sentiment category (positive or negative) and sentiment values of each piece of valid data ranging from -1 to 1 were obtained, with positive values indicating positive sentiment of the news towards the topic. We will then use the annual average sentiment values to evaluate simulated cooperation demand of downstream countries.

Because the analyzed newspaper needs to be in English due to the language difficulty, we could obtain continuous and relevant English newspapers only in Thailand among the downstream countries, while the other riparian countries did not have English language newspapers with broad coverage. The data processing is similar to that used in Wei et al. (2020), but we adjusted the key words and filtering rules to fit our goals. From the database of LexisNexis, we extracted in total 4622 pieces of data with keywords related to the dam constructions and regulations in China and Laos, published in Thai newspapers. Then we selected 592 pieces of relevant articles by removing duplicates and irrelevant news manually. The 592 valid pieces of news cover the period of 2000 2018. Through automatic analysis and manual correcting, the sentiment values of each piece of news are chosen for statistical analysis, averaged for each year.

\section{Results}

\subsection{Hydrological simulation and reservoir operation}

As shown in Fig. 5, the simulations at Jinghong, Chiang Saen, Luang Prabang and Pakse perform well with NSEs (Nash-Sutcliffe efficiency coefficients) above 0.8 for the calibration period. The NSEs of the validation period at the four stations are 0.84, 0.80, 0.79 and 0.87 respectively. For most years, the simulations of troughs during dry seasons and peaks during flood seasons are reproduced rather well, except for some extreme flood events when simulations un- derestimated the flow. The NSEs at Nong Khai and Nakhon Phanom reach 0.81 and 0.75 respectively, which indicates the applicability of the THREW model at different locations across the Lancang-Mekong River basin.

According to the observations and simulations, the annual discharge from China to downstream countries at Jinghong station ( $Q_{3}$ in Fig. 4) accounts for $66 \%$ of the discharge at Chiang Saen $\left(Q_{4}\right.$ in Fig. 4$)$ and $20 \%$ of the discharge at Pakse ( $Q_{7}$ in Fig. 4). As simplified in Fig. 4, runoff observed in Laos and Thailand accounts for $23 \%$ and $57 \%$ of the discharge at Pakse. The proportions of China and Laos in Pakse runoff are higher during non-flood seasons (November to May), and the change in seasonality of discharge in China and Laos caused by reservoir operations could affect the discharge and thus economic benefits in downstream countries.

Water releases from Xiaowan, Nuozhadu and the virtual Laos reservoir vary under the three scenarios, i.e., NC, FC and WA scenarios, and we compare them with natural water release without reservoir operation (NR scenario) during non-flood seasons. We set the initial reservoir storage to maximum storage at the beginning of the year and simulate the water release under two natural hydrological conditions, i.e., dry year of 2015 and normal year of 2017. Initial values of the cooperation level of China and Laos are both set to 0.5 .

As shown in Fig. 6, for both dry and normal years, the NC scenario keeps the largest storage and the FC scenario keeps the lowest storage. In a dry year like 2015, with the same cooperation level as in the normal year of 2017, reservoir storage under FC and WA scenarios is lower to satisfy the demands of downstream countries. Water releases from the three reservoirs under different scenarios in nonflood seasons in 2015 and 2017 are shown in Fig. 7. The final weighted average water releases (WA scenario) from Nuozhadu and Laos reservoirs to downstream countries are higher than natural water releases (NR scenario) during nonflood season (November to May), especially in the dry year of 2015. It is consistent with the phenomenon that reservoir operations increase discharge during non-flood seasons in downstream countries in recent years.

As shown in Fig. 8, the simulated reservoir storage under the continuous WA scenario is lower than the simulated storage under the continuous NC scenario in all three reservoirs. As a cooperative action, reservoir regulations under the continuous WA scenario keep releasing more water, particularly during dry years when the demands of downstream countries are high.

\subsection{Economic benefit}

Overall, the economic benefit simulations under WA scenario in each country and sector are reasonable compared to statistical data, as listed in Table 4. Under the continuous WA scenario, China and Laos have obtained increasing benefits mainly due to ongoing dam construction. As Fig. 9 shows, the simulated hydropower benefits of China 

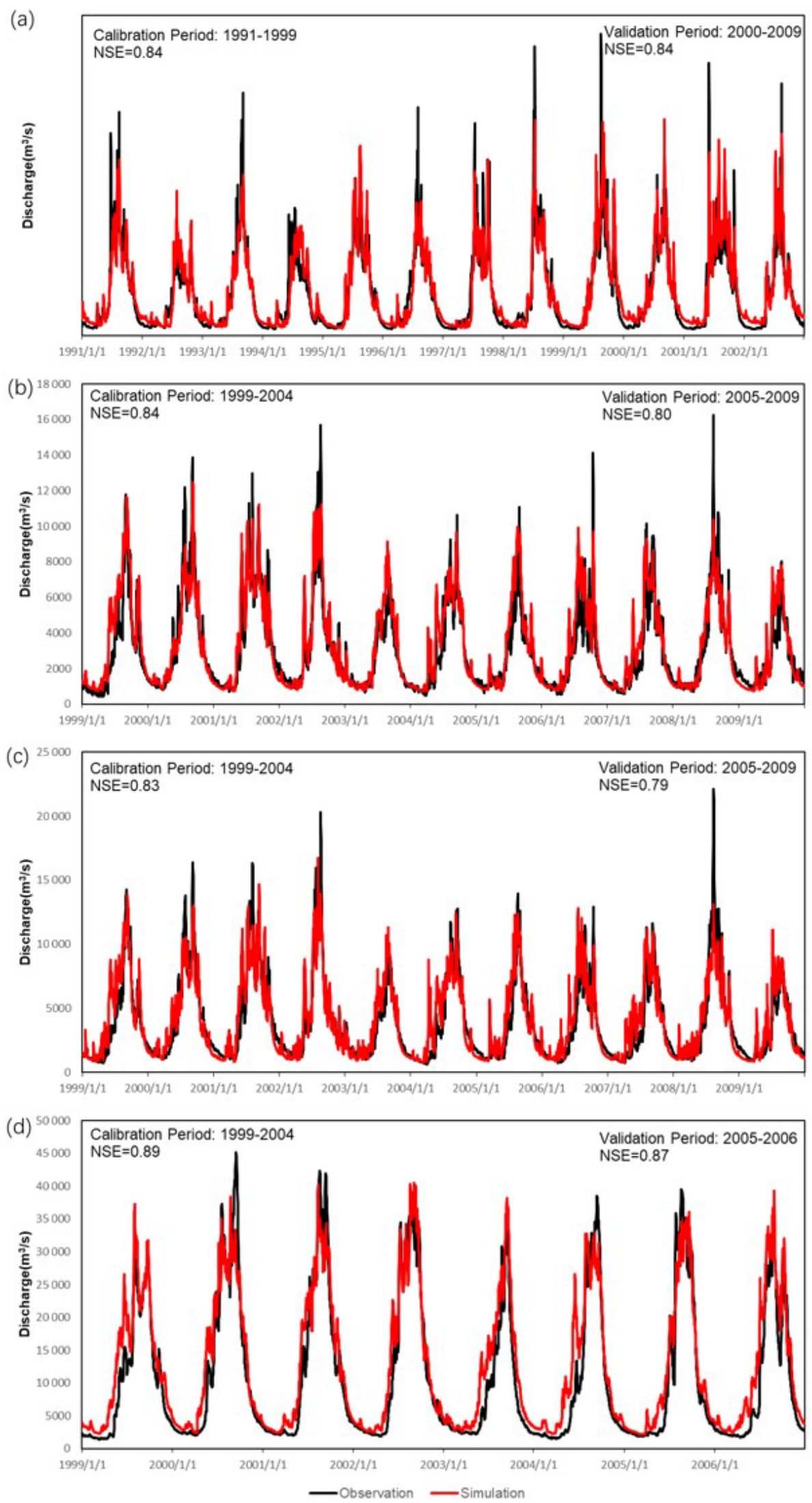

Figure 5. Daily Runoff simulations at Jinghong (a), Chiang Saen (b), Luang Prabang (c) and Pakse (d). 

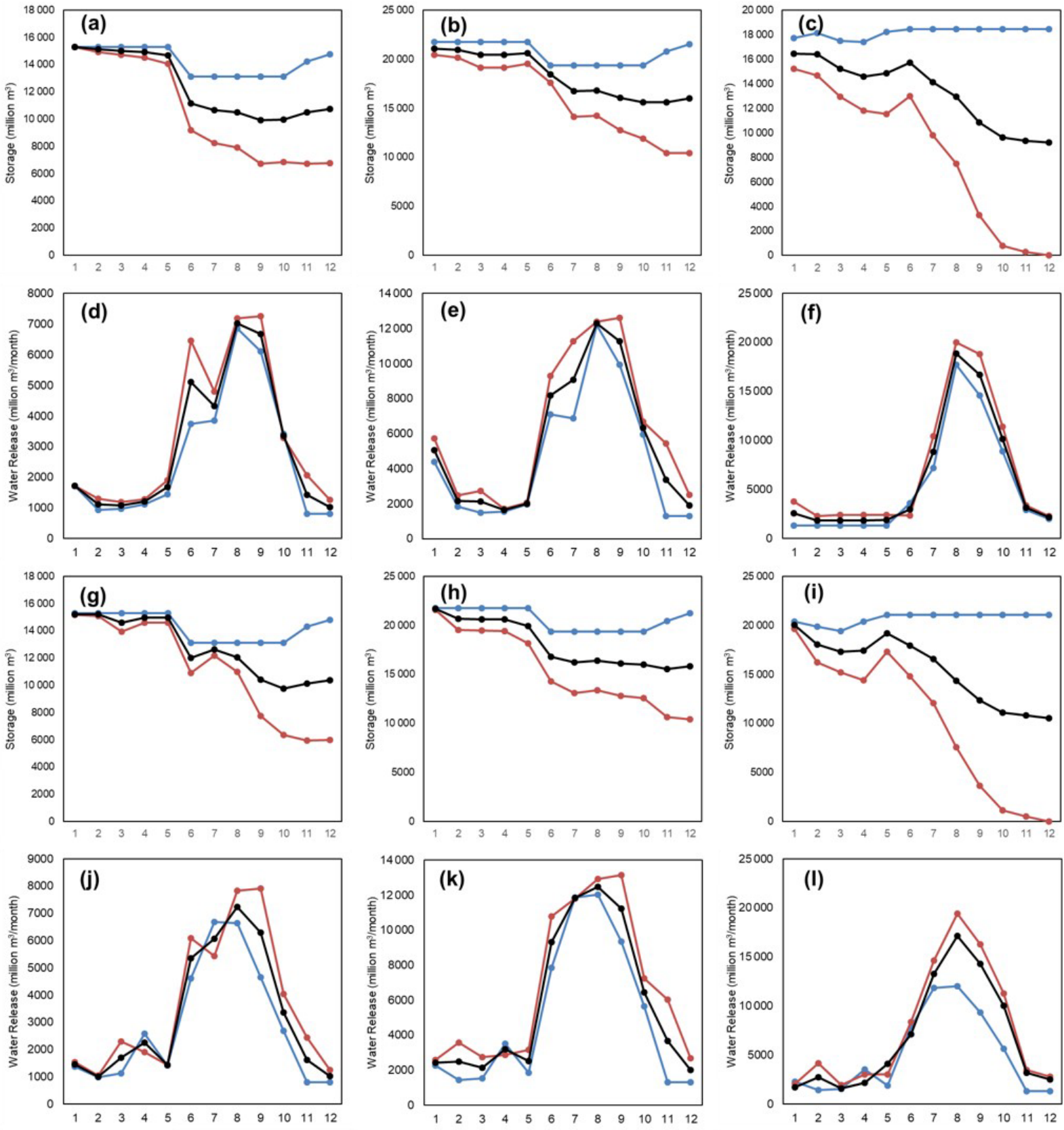

$\rightarrow$ non-cooperation scenari

$\rightarrow$ full-cooperation scenario

weighted average scenario

Figure 6. Reservoir storage and water release simulations of Xiaowan, Nuozhadu and Laos reservoirs in 2015 and 2017. (a) Xiaowan reservoir storage in 2015. (b) Nuozhadu reservoir storage in 2015. (c) Virtual Laos reservoir storage in 2015. (d) Water release of Xiaowan reservoir in 2015. (e) Water release of Nuozhadu reservoir in 2015. (f) Water release of the virtual Laos reservoir in 2015. (g) Xiaowan reservoir storage in 2017. (h) Nuozhadu reservoir storage in 2017. (i) Virtual Laos reservoir storage in 2017. (j) Water release of Xiaowan reservoir in 2017. (k) Water release of Nuozhadu reservoir in 2017. (l) Water release of the virtual Laos reservoir in 2017.

approached USD 2000 million in 2018, while the annual generation of the two reservoirs is close to 40 billion $\mathrm{kWh}$ (Yu et al., 2019b). The Laos reservoir generated hydropower around USD 976 million while the statistical estimation of hydropower benefit to Laos in 2015 is USD 1076 million (MRC, 2018), demonstrating the validity of economic ben- efit simulations in Laos. In Fig. 9a, the hydropower benefit of China under the WA scenario is lower than the NC scenario and higher than the FC scenario after 2012, indicating that cooperation actions (WA and FC) could harm the hydropower benefit of China. It is similar in Laos, as shown in Fig. 9b, but the benefits under WA resemble the NC sce- 


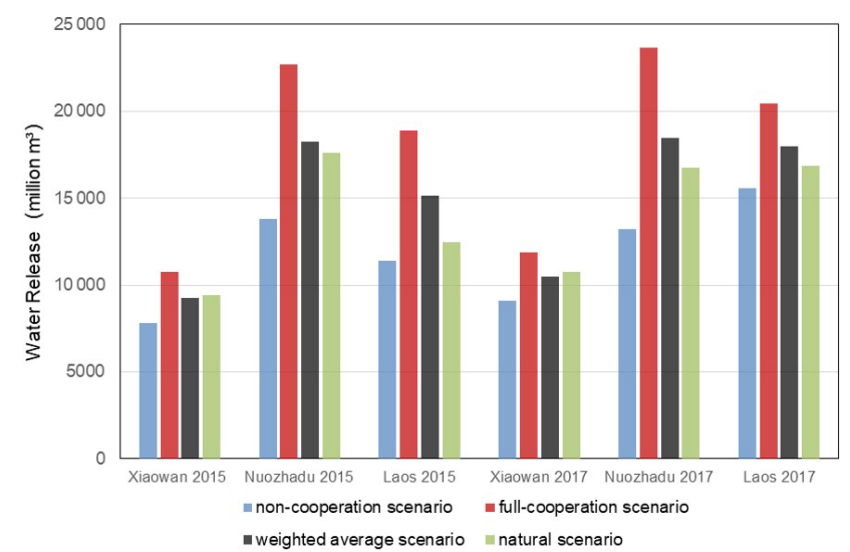

Figure 7. Water release of Xiaowan, Nuozhadu and virtual Laos reservoir in non-flood seasons in 2015 (dry year) and 2017 (normal year) under different scenarios.

Table 4. Simulated economic benefits in 2018 and statistical benefits.

\begin{tabular}{lrr}
\hline Unit: million USD & $\begin{array}{r}\text { Simulated } \\
\text { benefit }\end{array}$ & $\begin{array}{r}\text { Benefit from } \\
\text { statistical } \\
\text { data }\end{array}$ \\
\hline China hydropower & 1954 & 2000 \\
Laos hydropower & 976 & 1076 \\
Thailand agriculture & 1263 & 1314 \\
Thailand fishery & 118 & 120 \\
Cambodia agriculture & 593 & 592 \\
Cambodia fishery & 1160 & 1188 \\
Vietnam agriculture & 1728 & 2727 \\
Vietnam fishery & 179 & 195 \\
\hline
\end{tabular}

nario more due to the low cooperation level of Laos. The differences between the blue and red lines indicate the losses China and Laos need to bear if they cooperate altruistically to satisfy downstream demands and maximize downstream benefits.

When the two major reservoirs in China went into operation and cooperation levels increased after 2012, the total benefits of the three downstream countries under the WA scenario were higher than the NC scenario, although they cannot reach the high level of the FC scenario when China and Laos operate reservoirs merely for downstream benefits, as shown in Fig. 10a. The increase in downstream benefits under the WA scenario is remarkable compared to the NC scenario (e.g., USD 685 million in 2018). Comparing the results in Figs. 9 and 10, under the WA scenario, the loss China and Laos need to bear is less than the gain of downstream countries in most years, which help to rationalize the cooperation actions and is consistent with the outcomes of simulations in other studies (Yu et al., 2019b; Li et al., 2019; Do et al., 2020). Notably, in the dry years of 2015-2016, cooperative action of upstream countries could mitigate the losses of downstream countries, but downstream benefits would still be lower compared to those in normal years.

The downstream benefits of agriculture and fishery under the WA scenario are shown in Fig. 10b. The simulated agriculture benefit in 2018 is around USD 3600 million with irrigation withdrawals of 39 billion $\mathrm{m}^{3}$, while the statistical irrigation withdrawal of the three countries is $47{\text { billion } \mathrm{m}^{3}}^{3}$ (FAO, 2019). The simulated agriculture benefits of Thailand, Cambodia and Vietnam are USD 1263, 593 and 1728 million respectively, which are consistent with the statistical values for irrigated rice in Table 4, i.e., USD 1314, 592 and 2727 million (Cramb, 2020; MRC, 2018).

As for the capture fishery benefits, the losses during the years of reservoir filling and droughts are remarkable, approaching USD 215 and 162 million in 2010 and 2015 respectively. The reduction of fishery capture is consistent with the outcomes of study by Orr et al. (2012), which estimated that losses of fishery capture could reach $20 \%$ with the impacts of the upstream dams. In 2018, the simulated fishery benefits of Thailand, Cambodia, Vietnam and the total fishery benefit are USD 118, 1160, 179 and 1457 million, while the corresponding statistical values are USD 120, 1188, 195 and 1503 million. The statistical fishery values are estimated on the basis of fishery production (Burbano et al., 2020) and fishery prices (MRC, 2018). Overall, the simulated benefits of downstream countries in the three economic sectors are basically consistent with statistical values.

\subsection{Cooperation demand and level}

In Fig. 11a, the simulated cooperation demands reached high levels in 2004-2005, 2008, 2010, 2012-2013 and 20152016. These peaks are caused by benefit losses compared to other years. The losses in 2004-2005 and 2015-2016 arose from recorded droughts (MRC, 2018), while the losses in 2010 and 2012-2013 are related to the constructions and operations of Xiaowan and Nuozhadu dam.

As shown in Fig. 11a, the cooperation level of Laos increased from the start at a slow speed and exceeded 0.33 in 2018. The recent fluctuation of cooperation level of Laos could be reflected by the ongoing disputes and negotiations between Laos and other MRC members in respect of reservoir construction by Laos on the mainstream of the Mekong River since 2009 (Hensengerth, 2015). The cooperation levels of China increased since the completion of the first major dam construction in 2010. The cooperation level of China exceeded that of Laos in 2016, and the rapid increase in the cooperation level of China could be evidenced by China's cooperative actions in recent years, including initiation of the Lancang-Mekong Cooperation (LMC) framework in 2015, which is a much broader framework that goes beyond water cooperation, and implementation of emergency water release to mitigate the negative impacts of droughts downstream when the historically severe drought hit Mekong basin in 2015 and 2016 (Middleton and Allouche, 2016). 

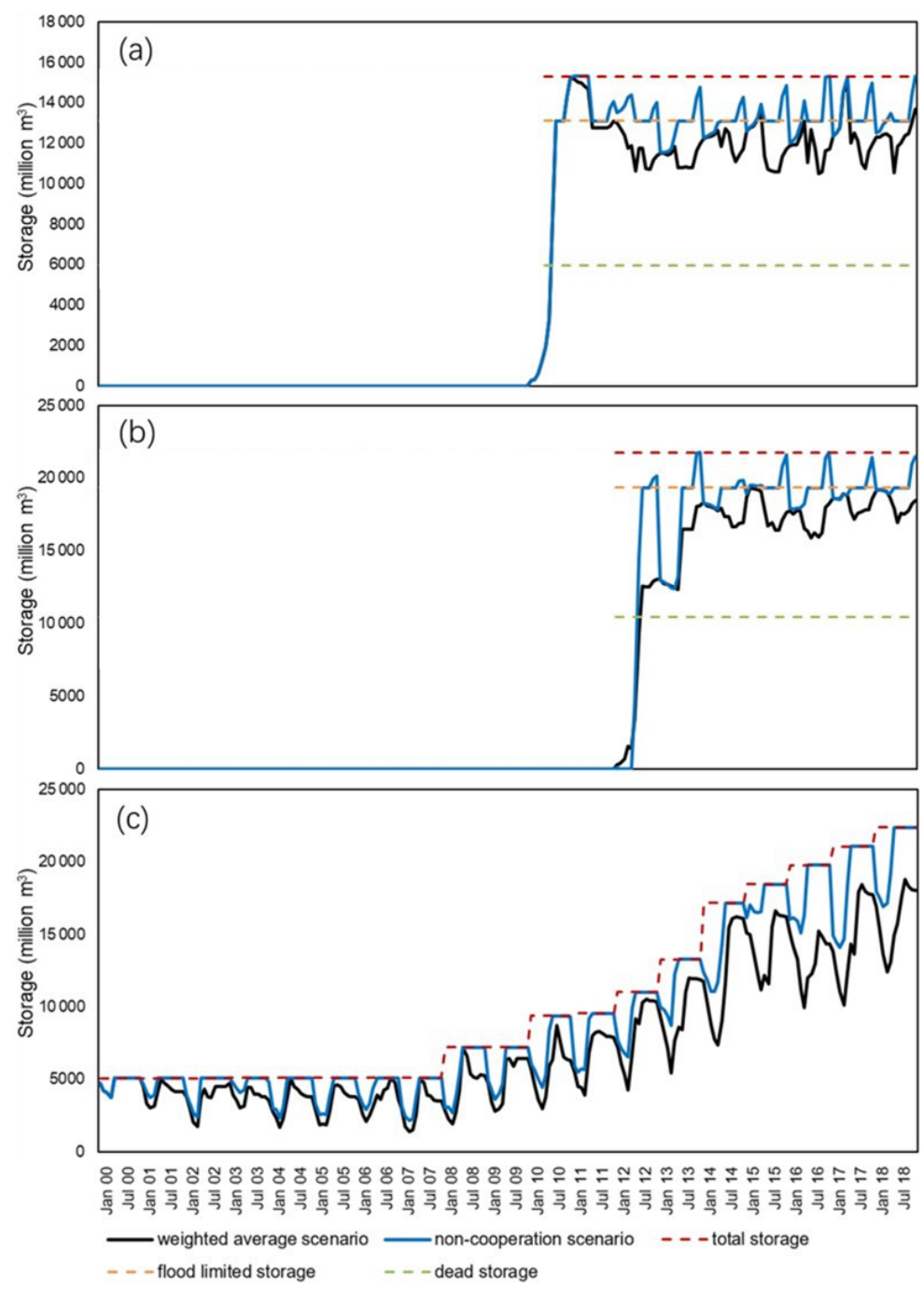

Figure 8. Simulated storage dynamics of Xiaowan (a), Nuozhadu (b) and virtual Laos reservoir (c). Total storage in panel (c) indicates total active storage of the virtual Laos reservoir.

As shown in Fig. 11b, the number of news articles concerning the impacts of upstream reservoirs increased significantly after 2010 , from less than 20 pieces each year to over 70 pieces in recent years. The means of sentiment values fluctuate greatly in early years. In 2004, 2010-2012 and 2015, sentiment results reached low values through the years, reflecting that the concerns and criticisms from Thailand towards China and Laos on dam operation were high compared to normal years. The dynamics of sentiment values are basically consistent with the simulations of cooperation demand shown in Fig. 11c. Simulated cooperation demands are high during 2005, 2008, 2010, 2012-2013 and 2015-2016. Similar to the cooperation demand of the three downstream countries introduced before, the peaks of cooperation demand and concerns from downstream in 2005 and 2015 are ascribed to droughts and losses, while the concerns in 2010 and 2012 are due to the effects of dam constructions at Xiaowan and
Nuozhadu during these two years. Besides the factors mentioned above, based on the text information of news, another reason why concerns increased in 2010-2012 is that Laos started to construct the Xayaburi Dam, which is the first dam Laos constructed on the mainstream of the Mekong River and is regarded as a violation of the 1995 Mekong Agreement (Herbertson, 2013). Overall, our simulations of cooperation demands reflect the empirical dynamics of downstream countries obtained through sentiment analyses. Uncertainty analysis in Fig. 12 shows that although the selection of these six critical parameters could lead to uncertainty of the simulated cooperation demand downstream, the trend and fluctuation pattern of the simulations are consistent, which proves the reliability of the simulations. It should be noted that while the given values of political factors lead to similarity in cooperation demands in Fig. 12, the impacts of certain parameter 

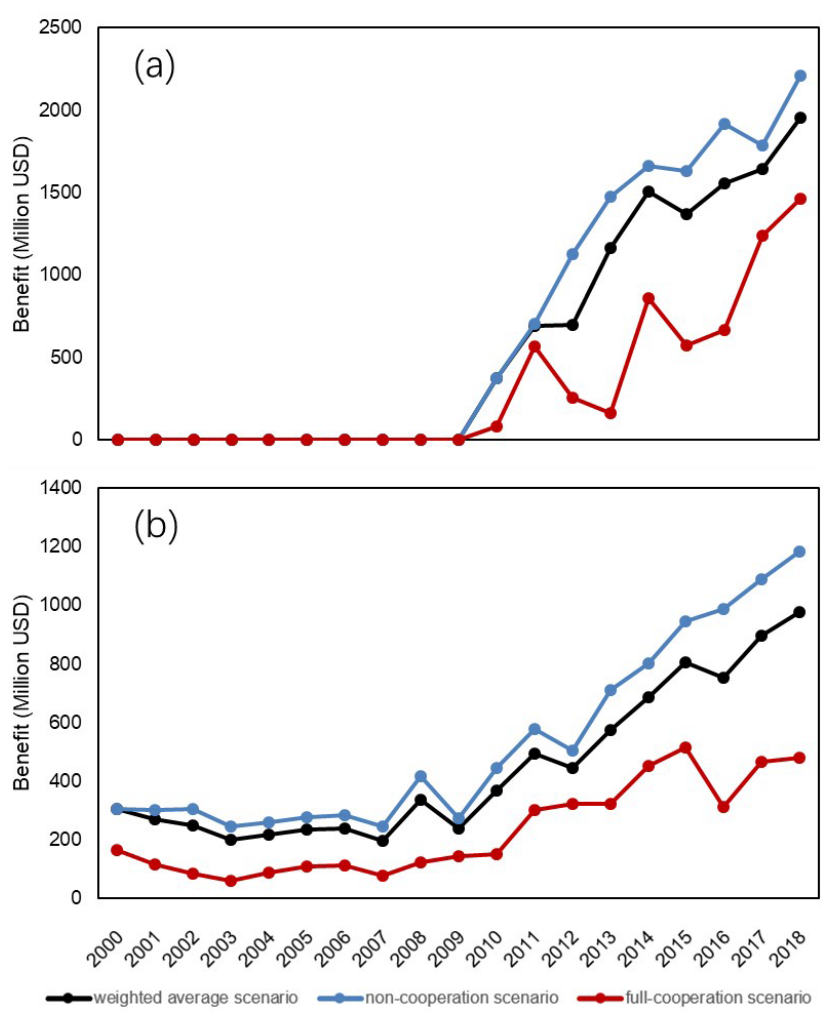

Figure 9. Benefit of upstream China (a) and Laos (b) under the weighted average scenario, non-cooperation scenario and fullcooperation scenario.

on simulation should be investigated with a larger range of values and more tests, which is left for future research.

\section{Discussion and conclusions}

This paper presented the development and application of a coupled socio-hydrological model to simulate the dynamics of cooperation and conflict in the transboundary LancangMekong River basin in Southeast Asia. The LancangMekong River is a typical transboundary river where the upstream mountainous area is rich in hydropower and lower plain areas are suitable for irrigation and are rich in fisheries. Dam construction and operations in upstream countries (China, Laos) have changed the seasonality of downstream river flows, which have impacted the benefits gained by downstream countries, notably in terms of agriculture and fishery, both of which rely on the discharge of rivers. When downstream countries faced benefit losses compared to maximum benefits as a result, they led to community concerns, which they tend to blame on upstream countries. Once the dams were constructed and were in place, the most available and effective cooperative action to avoid regional conflicts was to operate the reservoirs in a way to achieve basin-wide synergy between upstream and downstream countries (Do
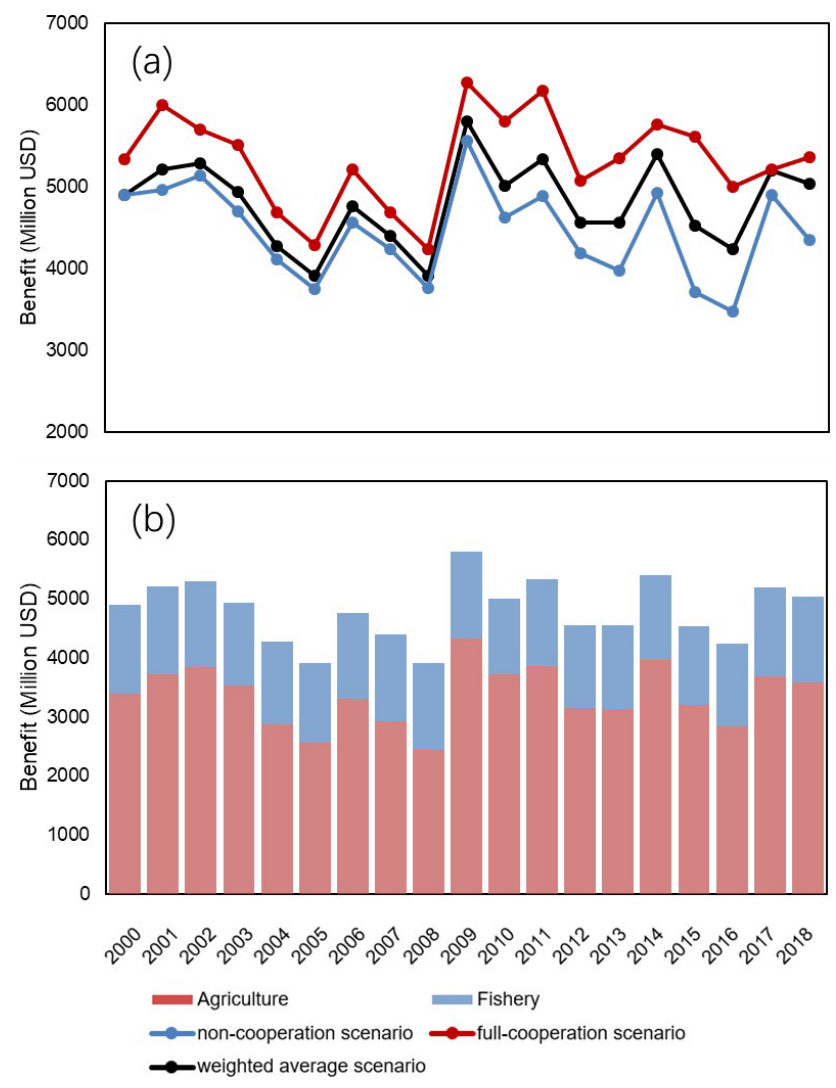

Figure 10. (a) Benefits of Thailand, Cambodia and Vietnam under the weighted average scenario, non-cooperation scenario and fullcooperation scenario. (b) Agriculture and fishery benefits of downstream under the weighted average scenario.

et al., 2020). While upstream countries may have lost some economic benefits by sacrificing some of their hydropower generation to benefit downstream countries, by doing so they also stood to gain more indirect political and economic benefits, e.g., better diplomatic relations and more investment opportunities in downstream countries (Sadoff and Grey, 2002).

The socio-hydrological model presented in this paper was able to capture the dynamics of such cooperation and conflict through the coupling of modules representing hydrology, reservoir operation, economic benefits and policy, which is simple but comprehensive. The interplay among hydrological, economic and political factors is important, because hydrological variability and human activities could impact the dynamics of cooperation jointly. The model simulations perform well against empirical observations of runoff, published statistics of economic benefits in the different sectors and sentiment analysis results.

A novel feature of the model is the quantification of cooperation dynamics in the form of a logit dynamics model. The logit dynamics model operates in such a way that willingness to cooperate increases when there are greater benefits to be gained if the parties cooperate and fewer benefits if they do 


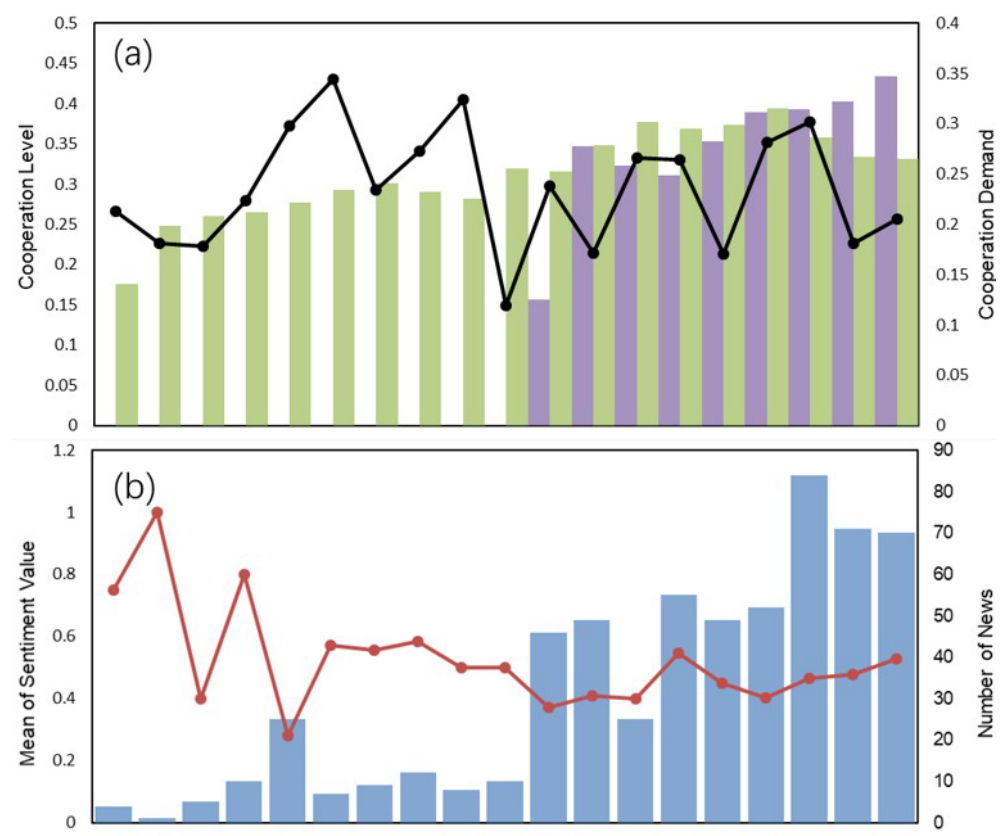

$\begin{array}{lllllllllllllllllll}00 & 01 & 02 & 03 & 04 & 05 & 06 & 07 & 08 & 09 & 10 & 11 & 12 & 13 & 14 & 15 & 16 & 17 & 18\end{array}$

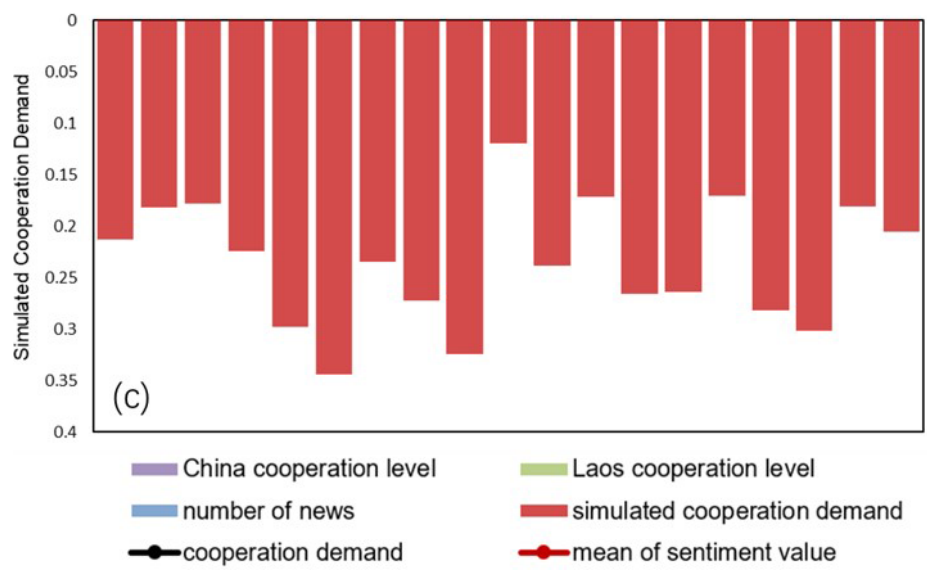

Figure 11. (a) Simulation of cooperation demand of downstream and cooperation level of China and Laos. (b) Newspaper sentiment analysis of Thailand. (c) Simulation of cooperation demand of Thailand.

not. A particular strength of the logit model is that it could explicitly include geopolitical factors that add to the indirect benefits that upstream countries may gain through increased cooperation. When upstream countries value the indirect political benefits more and are thus more responsive to the downstream concerns, the cooperation level would increase, which is quantified in the model to represent to what extent the upstream country would like to accommodate downstream water demands in reservoir operation. The increase in the simulated cooperation level is consistent with the cooperative actions taken by China in recent years. Over the last two decades, cooperation demands of the downstream countries increased over drought years and over the years of reservoir filling. The surge of downstream concerns towards upstream countries needs to be treated appropriately; otherwise the concerns could turn into more severe conflicts. The losses of the downstream relative to maximum expected benefits could be mitigated by cooperative actions of upstream countries, i.e., change in reservoir regulation, which will lead to less concern and less criticism from downstream countries. Compared with the extant models, this socio-hydrological model is the first one, to the best of our knowledge, to include the co-evolutionary transboundary river cooperation as an internal variable instead of as a static and external variable in coupled hydrology-economic models. This particular feature enables the model to analyze the mid- and long-term cooperation dynamics in transboundary rivers.

The cooperation dynamics in the Lancang-Mekong River basin described in the socio-hydrologic model are common in many other transboundary river basins. In particular, losses compared to expected benefits of downstream countries from the actions of upstream countries, such as dam construction, 

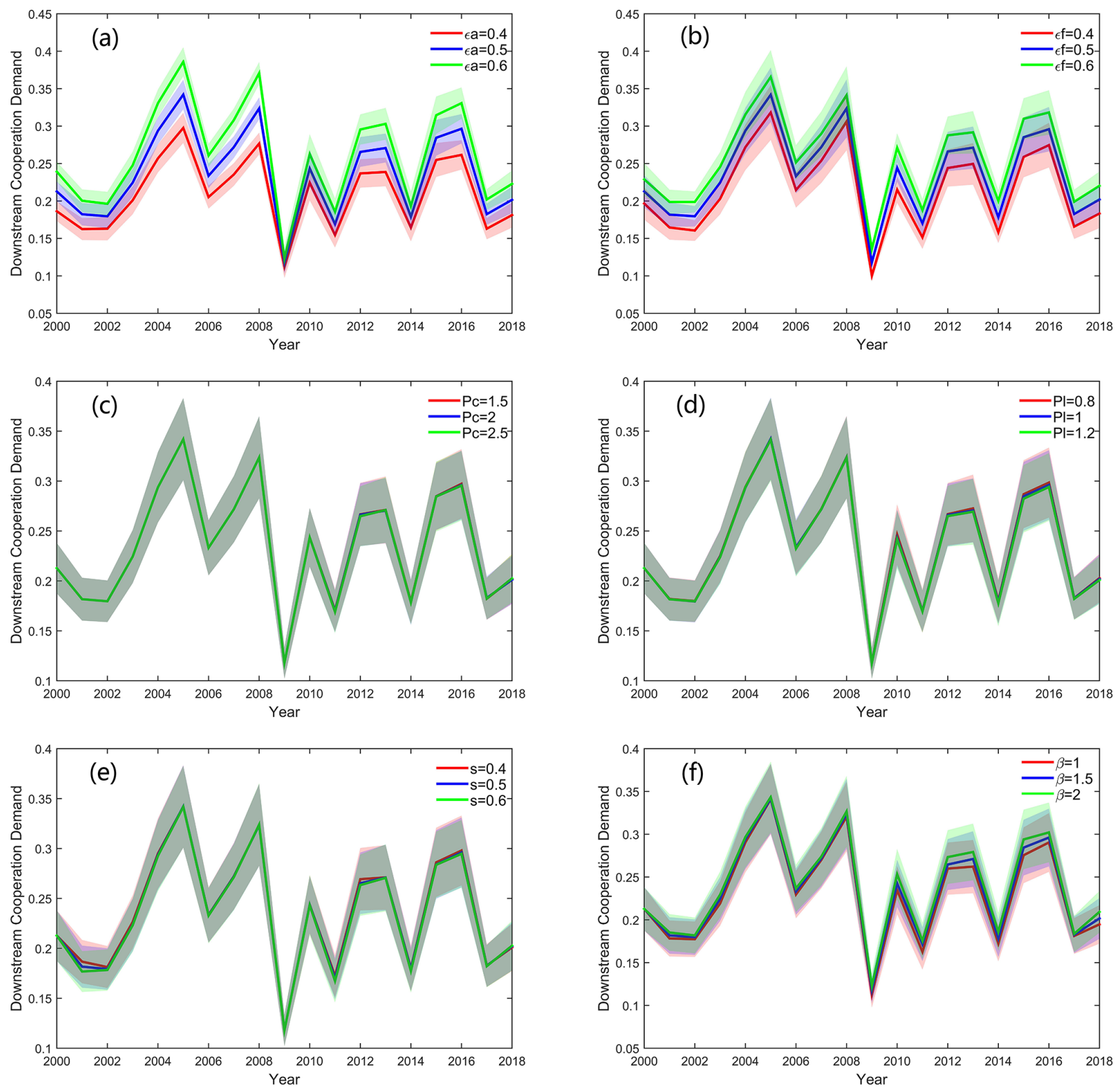

Figure 12. Uncertainty analysis of critical parameters in the socio-hydrological model. (a) Sensitivity of agriculture loss. (b) Sensitivity of fishery loss. (c) China political factor. (d) Laos political factor. (e) Responsive change rate. (f) Shape parameter.

water extraction and pollution, can be counterbalanced by the willingness to cooperate by upstream countries, by sharing some economic benefits with downstream countries as compensation for their loss compared to expected benefit, in return for indirect geopolitical benefits and investment opportunities. By capturing these mechanisms and by accounting for the effects of hydrologic variability and reservoir releases on the economic benefits of the various water uses in the quantification of willingness to cooperate, the sociohydrological model presented in this paper provides an objective scientific framework to underpin transboundary water management and negotiations elsewhere.
As an early version transboundary river sociohydrological model, there is significant room for further improvement in the model formulation. With limited research and knowledge on the quantification of cooperation and political benefits, the parameterization of a policy feedback module such as the political factor is relatively primitive. As the model is applied to more cases, these policy feedback parameters could be investigated to find some general patterns, which could be then used to determine the corresponding parameters a priori when applying to new cases. The current model simulated the effect of hydroelectric power generation in multiple dams in China and Laos in a lumped manner, which has a negative impact 
on the accuracy of reservoir releases and hence on benefit calculation for downstream countries. The situation can be improved in the future through more distributed simulation of the cascade of reservoirs. Additionally, in order to integrate the complex hydro-economic relationships into the model, agriculture and fishery benefits are calculated in the present model with rather simplified equations. There is room for significant improvement in these benefit calculations. Flood control is one of the most important functions of existing and planned future dams but has been ignored in this study, which may have led to underestimation of the benefits to both upstream and downstream countries. Simulations under different scenarios of climate change and human activities could provide projections of the dynamics of transboundary river cooperation and conflict and thus provide useful insights for transboundary river management in the future.

Code and data availability. The data are available on request from the corresponding author (tianfq@mail.tsinghua.edu.cn).

Author contributions. YL, FT, LG, IB and RP discussed the framework of the socio-hydrologic model. You Lu developed the model code and performed the simulations. JW, DL, YW and DJY discussed and revised the model. YL and FT prepared the manuscript, with significant inputs and edits by YW, DJY and MS, as well as with contributions from all co-authors. FT supervised the whole procedure of this study.

Competing interests. The authors declare that they have no conflict of interest.

Special issue statement. This article is part of the special issue "Socio-hydrology and transboundary rivers". It is not associated with a conference.

Acknowledgements. We would like to acknowledge the National Natural Science Foundation of China (51961125204), the Ministry of Science and Technology of China (2016YFA0601603), and the National Natural Science Foundation of China (51779203) for financial support. We also acknowledge the support from the 2019 Summer Institute on Socio-hydrology and Transboundary Rivers held in Yunnan University, China.

Financial support. This research has been supported by the Ministry of Science and Technology of China (grant no. 2016YFA0601603) and the National Natural Science Foundation of China (grant nos. 51961125204 and 51779203).
Review statement. This paper was edited by Giuliano Di Baldassarre and reviewed by Gopal Penny and two anonymous referees.

\section{References}

Abdul, G. N., Suraya, H., Abaker, T. H. I., and Ejaz, A.: Social Media Big Data Analytics: A Survey, Comput. Human Behav., 101, 417-428, https://doi.org/10.1016/j.chb.2018.08.039, 2019.

Allen, R. G., Pereira, L. S., Raes, D., and Smith, M.: Crop evapotranspiration - Guidelines for computing crop water requirements, FAO Irrigation and drainage paper 56, FAO, Rome, 87210, 1998.

Arjoon, D., Tilmant, A., and Herrmann, M.: Sharing water and benefits in transboundary river basins, Hydrol. Earth Syst. Sci., 20, 2135-2150, https://doi.org/10.5194/hess-20-2135-2016, 2016.

Baran, E. and Cain, J.: Ecological approaches of flood-fish relationships modelling in the Mekong River, in: Proceedings of the National workshop on Ecological and Environmental Modelling, 34 September 2001, Universiti Sains Malaysia, Penang, Malaysia, 2001.

Basheer, M., Wheeler, K. G., Ribbe, L., Majdalawi, M., Abdo, G., and Zagona, E. A.: Quantifying and evaluating the impacts of cooperation in transboundary river basins on the Water-EnergyFood nexus: The Blue Nile Basin, Sci. Total Environ., 630, 13091323, 2018.

Beck, L., Bernauer, T., Siegfried, T., and Böhmelt, T.: Implications of hydro-political dependency for international water cooperation and conflict: Insights from new data, Polit. Geogr., 42, 2333, https://doi.org/10.1016/j.polgeo.2014.05.004, 2014.

Bernal, J. M. and Solís, A. H.: Conflict and Cooperation on International Rivers: The Case of the Colorado River on the US-Mexico Border, Int. J. Water Resour. Dev., 16, 651-660, 2000.

Bernauer, T., Böhmelt, T., Buhaug, H., Gleditsch, N. P., Tribaldos, T., Weibust, E. B., and Wischnath, G.: Water-related intrastate conflict and cooperation (WARICC): a new event dataset, Int. Interact., 38, 529-545, https://doi.org/10.1080/03050629.2012.697428, 2012.

Bravo-Marquez, F., Mendoza, M., and Poblete, B.: Meta-level sentiment models for big social data analysis, Knowledge Syst., 69, 86-99, 2014.

Burbano, M., Shin, S., Nguyen, K., and Pokhrel, Y.: Hydrologic changes, dam construction, and the shift in dietary protein in the Lower Mekong River Basin, J. Hydrol., 581, 124454, https://doi.org/10.1016/j.jhydrol.2019.124454, 2020.

Cai, X., McKinney, D. C., and Lasdon, L. S.: Integrated hydrologicagronomic-economic model for river basin management, J. Water Resour. Plan. Manage., 129, 4-17, 2003.

Campbell, I. C.: Integrated management in the Mekong River Basin, Ecohydrol. Hydrobiol., 16, 255-262, 2016.

Cramb, R.: The Evolution of Rice Farming in the Lower Mekong Basin, Palgrave Macmillan, Singapore, 2020.

De Bruyne, C. and Fischhendler, I.: Negotiating conflict resolution mechanisms for transboundary water treaties: A transaction cost approach, Global Environ. Change, 23, 1841-1851, https://doi.org/10.1016/j.gloenvcha.2013.07.009, 2013.

De Stefano, L., Edwards, P., de Silva, L., and Wolf, A. T.: Tracking cooperation and conflict in international basins: 
historic and recent trends, Water Policy, 12, 871-884, https://doi.org/10.2166/wp.2010.137, 2010.

De Stefano, L., Petersen-Perlman, J. D., Sproles, E. A., Eynard, J., and Wolf, A. T.: Assessment of transboundary river basins for potential hydro-political tensions, Global Environ. Change, 45, 35-46, https://doi.org/10.1016/j.gloenvcha.2017.04.008, 2017.

Di Baldassarre, G., Sivapalan, M., Rusca, M., Cudennec, C., Garcia, M., Kreibich, H., Konar, M., Mondino, E., Mård, J., Pande, S., Sanderson, M. R., Tian, F., Viglione, A., Wei, J., Wei, Y., Yu, D. J., Srinivasan, V., and Blöschl, G.: Sociohydrology: Scientific Challenges in Addressing the Sustainable Development Goals, Water Resour. Res., 55, 6327-6355, https://doi.org/10.1029/2018wr023901, 2019.

Dinar, A., Blankespoor, B., Dinar, S., and Kurukulasuriya, P.: Does precipitation and runoff variability affect treaty cooperation between states sharing international bilateral rivers?, Ecol. Econ., 69, 2568-2581, https://doi.org/10.1016/j.ecolecon.2010.07.036, 2010.

Dinar, S.: Scarcity and cooperation along international rivers, Global Environ. Polit., 9, 109-135, 2009.

Do, P., Tian, F., Zhu, T., Zohidov, B., Ni, G., Lu, H., and Liu, H.: Exploring Synergies in the Water-Food-Energy Nexus by Using an Integrated Hydro-Economic Optimization Model for the Lancang-Mekong River Basin, Sci. Total Environ., 728, 137996, https://doi.org/10.1016/j.scitotenv.2020.137996, 2020.

Doorenbos, J. and Kassam, A. H.: Yield response to water, Irrigation and Drainage Paper No. 33, FAO, Rome, 1979.

Dudgeon, D.: Large-scale hydrological changes in tropical Asia: prospects for riverine biodiversity: the construction of large dams will have an impact on the biodiversity of tropical Asian rivers and their associated wetlands, BioScience, 50, 793-806, 2000.

Espey, M. and Towfique, B.: International bilateral water treaty formation, Water Resour. Res., 40, W05S05, https://doi.org/10.1029/2003WR002534, 2004.

FAO: Rice and narrowing the yield gap, Rome Italy: Plant Production and Protection Division, Crop and Grassland Service, available at: http://www.fao.org/rice2004/en/f-sheet/factsheet5. pdf (last access: 7 April 2021), 2004.

FAO: Crop Water Information, Food and Agriculture Organization of the United Nations Statistics Division, available at: http://www.fao.org/land-water/databases-and-software/ crop-information/en/ (last access: 7 April 2021), 2019.

Feng, Y., Wang, W., Suman, D., Yu, S., and He, D.: Water Cooperation Priorities in the Lancang-Mekong River Basin Based on Cooperative Events Since the Mekong River Commission Establishment, Chinese Geogr. Sci., 29, 58-69, https://doi.org/10.1007/s11769-019-1016-4, 2019.

Frisvold, G. B. and Caswell, M. F.: Transboundary water management Game-theoretic lessons for projects on the US-Mexico border?, Agricult. Econ., 24, 101-111, 2000.

Giuliani, M. and Castelletti, A.: Assessing the value of cooperation and information exchange in large water resources systems by agent-based optimization, Water Resour. Res., 49, 3912-3926, https://doi.org/10.1002/wrcr.20287, 2013.

Hamlet, A. F.: The Role of Transboundary Agreements in the Columbia River Basin, Springer, Dordrecht, 2003.

Han, Z., Long, D., Fang, Y., Hou, A., and Hong, Y.: Impacts of climate change and human activities on the flow regime of the dammed Lancang River in Southwest China, J. Hydrol., 570, 96$105,2019$.

He, Z. H., Tian, F. Q., Gupta, H. V., Hu, H. C., and Hu, H. P.: Diagnostic calibration of a hydrological model in a mountain area by hydrograph partitioning, Hydrol. Earth Syst. Sci., 19, $1807-$ 1826, https://doi.org/10.5194/hess-19-1807-2015, 2015.

Hensengerth, O.: Where is the power? Transnational networks, authority and the dispute over the Xayaburi Dam on the Lower Mekong Mainstream, Water Int., 40, 911-928, 2015.

Herbertson, K.: Xayaburi Dam: How Laos Violated the 1995 Mekong Agreement, International Rivers, Berkeley, California, available at: https://data.opendevelopmentmekong. net/lo/dataset/bd77be0d-5d8c-477b-a595-08226f37b857/ resource/0051356f-9ac7-49ec-b084-990ccbaa025b/download/ intlriversanalysisofmekongagreementjanuary20130.pdf (last access: 7 April 2021), 2013.

Hoanh, C. T., Jirayoot, K., Lacombe, G., and Srinetr, V.: Impacts of climate change and development on Mekong flow regimes. First assessment - 2009, International Water Management Institute, Vientiane, Lao PDR, 2010.

Hofbauer, J. and Sigmund, K.: Evolutionary game dynamics, Bull. Am. Math. Soc., 40, 479-519, 2003.

Hortle, K., Pengbun, N., Rady, H., and Sopha, L.: Tonle Sap yields record haul, Catch Cult., 10, 2-5, 2005.

Iwasa, Y., Uchida, T., and Yokomizo, H.: Nonlinear behavior of the socio-economic dynamics for lake eutrophication control, Ecol. Econ., 63, 219-229, 2007.

Jiang, H., Lin, P., and Qiang, M.: Public-Opinion Sentiment Analysis for Large Hydro Projects, J. Construct. Eng. Manage., 142, 05015013, https://doi.org/10.1061/(ASCE)CO.19437862.0001039, 2016.

Kaboosi, K. and Kaveh, F.: Sensitivity analysis of FAO 33 crop water production function, Irrig. Sci., 30, 89-100, 2012.

Kahneman, D. and Tversky, A.: Prospect Theory: An Analysis of Decision Under Risk, Econometrica, 47, 263-291, 1979.

Kandasamy, J., Sounthararajah, D., Sivabalan, P., Chanan, A., Vigneswaran, S., and Sivapalan, M.: Socio-hydrologic drivers of the pendulum swing between agricultural development and environmental health: a case study from Murrumbidgee River basin, Australia, Hydrol. Earth Syst. Sci., 18, 1027-1041, https://doi.org/10.5194/hess-18-1027-2014, 2014.

Keskinen, M., Kummu, M., Käkönen, M., and Varis, O.: Mekong at the crossroads: Next steps for impact assessment of large dams, Ambio, 41, 319-324, 2012.

Kite, G.: Modelling the Mekong: hydrological simulation for environmental impact studies, J. Hydrol., 253, 1-13, 2001.

Li, D., Long, D., Zhao, J., Lu, H., and Hong, Y.: Observed changes in flow regimes in the Mekong River basin, J. Hydrol., 551, 217 232, 2017.

Li, D., Zhao, J., and Govindaraju, R. S.: Water benefits sharing under transboundary cooperation in the Lancang-Mekong River Basin, J. Hydrol., 577, 123989, https://doi.org/10.1016/j.jhydrol.2019.123989, 2019.

Li, H., Sivapalan, M., and Tian, F.: Comparative diagnostic analysis of runoff generation processes in Oklahoma DMIP2 basins: The Blue River and the Illinois River, J. Hydrol., 418, 90-109, 2012.

McCracken, M. and Wolf, A. T.: Updating the Register of International River Basins of the world, Int. J. Water Resour. Dev., 
35, 732-782, https://doi.org/10.1080/07900627.2019.1572497, 2019.

McFadden, D.: Econometric models of probabilistic choice, Structural analysis of discrete data with econometric applications, 198-272, available at: https://elsa.berkeley.edu/ $\sim$ mcfadden/discrete/ch5.pdf (last access: 7 April 2021), 1981.

Micklin, P.: The Aral Sea Crisis, in: Dying and Dead Seas Climatic Versus Anthropic Causes, NATO Science Series: IV: Earth and Environmental Sciences, vol. 36, edited by: Nihoul, J. C. J., Zavialov, P. O., and Micklin, P. P., Springer, Dordrecht, https://doi.org/10.1007/978-94-007-0967-6_5, 2004.

Middleton, C. and Allouche, J.: Watershed or powershed? Critical hydropolitics, China and the 'Lancang-Mekong cooperation framework', Int. Spectat., 51, 100-117, 2016.

Mou, L., Tian, F., Hu, H., and Sivapalan, M.: Extension of the Representative Elementary Watershed approach for cold regions: constitutive relationships and an application, Hydrol. Earth Syst. Sci., 12, 565-585, https://doi.org/10.5194/hess-12565-2008, 2008.

MRC: Agreement on the cooperation for the sustainable development of the Mekong River Basin, Mekong River Commission Secretariat, Vientiane, Lao PDR, 1995.

MRC: Assessment of Basin-Wide Development Scenarios - Main Report, Mekong River Commission, Vientiane, Lao PDR, 2010.

MRC: Summary State of the Basin Report 2018, Mekong River Commission, Vientiane, Lao PDR, ISSN 1728-3248, 2018.

Müller, M. F., Müller-Itten, M. C., and Gorelick, S. M.: How Jordan and Saudi Arabia are avoiding a tragedy of the commons over shared groundwater, Water Resour. Res., 53, 5451-5468, 2017.

Munia, H., Guillaume, J. H. A., Mirumachi, N., Porkka, M., Wada, Y., and Kummu, M.: Water stress in global transboundary river basins: significance of upstream water use on downstream stress, Environ. Res. Lett., 11, 014002, https://doi.org/10.1088/17489326/11/1/014002, 2016.

Orr, S., Pittock, J., Chapagain, A., and Dumaresq, D.: Dams on the Mekong River: Lost fish protein and the implications for land and water resources, Global Environ. Change, 22, 925-932, 2012.

Petersen-Perlman, J. D., Veilleux, J. C., and Wolf, A. T.: International water conflict and cooperation: challenges and opportunities, Water Int., 42, 105-120, https://doi.org/10.1080/02508060.2017.1276041, 2017.

Pokhrel, Y., Burbano, M., Roush, J., Kang, H., Sridhar, V., and Hyndman, D. W.: A review of the integrated effects of changing climate, land use, and dams on Mekong river hydrology, Water, 10, 266, https://doi.org/10.3390/w10030266, 2018.

Reggiani, P., Sivapalan, M., and Hassanizadeh, S. M.: A unifying framework for watershed thermodynamics: balance equations for mass, momentum, energy and entropy, and the second law of thermodynamics, Adv. Water Resour., 22, 367-398, 1998.

Ringler, C.: Optimal allocation and use of water resources in theMekong River Basin: Multi-country and intersectoral analyses, in: Development Economics and Policy Series, Vol. 20, Peter Lang Verlag, Frankfurt, Germany, 2001.

Ringler, C. and Cai, X.: Valuing fisheries and wetlands using integrated economic-hydrologic modeling - Mekong River Basin, J. Water Resour. Plan. Manage., 132, 480-487, 2006.

Sadoff, C. and Grey, D.: Beyond the river: the benefits of cooperation on international rivers, Water Policy, 4, 389-403, 2002.
Sadoff, C. and Grey, D.: Cooperation on International Rivers A Continuum for Securing and Sharing Benefits, Water Int., 30, 18,2005

Schmidt, U.: Reference dependence in cumulative prospect theory, J. Math. Psychol., 47, 122-131, 2003.

Schultz, B.: Development of trans-boundary cooperation in the Rhine River Basin, Mekong River Commission, Vientiane, Lao PDR, 314-324, 2009.

Siegel, S.: Level of aspiration and decision making, Psycholog. Rev., 64, 253-262, 1957.

Sivapalan, M. and Bloschl, G.: Time scale interactions and the coevolution of humans and water, Water Resour. Res., 51, 69887022, 2015.

Song, J. and Whittington, D.: Why have some countries on international rivers been successful negotiating treaties? A global perspective, Water Resour. Res., 40, W05S06, https://doi.org/10.1029/2003wr002536, 2004.

Stone, R.: Dam-building threatens Mekong fisheries, Science, 354, 1084-1085, 2016.

Suzuki, Y. and Iwasa, Y.: The coupled dynamics of human socioeconomic choice and lake water system: the interaction of two sources of nonlinearity, Ecol. Res., 24, 479-489, 2009a.

Suzuki, Y. and Iwasa, Y.: Conflict between groups of players in coupled socio-economic and ecological dynamics, Ecol. Econ., 68 , 1106-1115, 2009b.

Teasley, R. L. and McKinney, D. C.: Calculating the Benefits of Transboundary River Basin Cooperation: Syr Darya Basin, J. Water Resour. Plan. Manage., 137, 481-490, https://doi.org/10.1061/(ASCE)WR.1943-5452.0000141, 2011.

Tian, F., Hu, H., Lei, Z., and Sivapalan, M.: Extension of the Representative Elementary Watershed approach for cold regions via explicit treatment of energy related processes, Hydrol. Earth Syst. Sci., 10, 619-644, https://doi.org/10.5194/hess-10619-2006, 2006.

Tian, F., Hu, H., and Lei, Z.: Thermodynamic watershed hydrological model: Constitutive relationship, Sci. China Ser. E, 51, 13531369, 2008.

Tian, F., Lu, Y., Hu, H., Kinzelbach, W., and Sivapalan, M.: Dynamics and driving mechanisms of asymmetric human water consumption during alternating wet and dry periods, Hydrolog. Sci J., 64, 507-524, 2019.

Tversky, A. and Kahneman, D.: Loss aversion in riskless choice: A reference-dependent model, Quart, J. Econ., 106, 1039-1061, 1991.

UNEP: Transboundary river basins: Status and trends, United Nations Environment Programme (UNEP), Nairobi, Kenya, 3, 1$12,2016$.

Urban, F., Siciliano, G., and Nordensvard, J.: China's dam-builders: Their role in transboundary river management in South-East Asia, Int. J. Water Resour. Dev., 34, 747-770, 2018.

Wang, W., Lu, H., Ruby Leung, L., Li, H. Y., Zhao, J., Tian, F., Yang, K., and Sothea, K.: Dam Construction in LancangMekong River Basin Could Mitigate Future Flood Risk From Warming-Induced Intensified Rainfall, Geophys. Res. Lett., 44, 10378-10386, 2017.

Weaver, D. A. and Bimber, B.: Finding news stories: a comparison of searches using LexisNexis and Google News, Journal. Mass Commun. Quart., 85, 515-530, 2008. 
Wei, J., Wei, Y., and Western, A.: Evolution of the societal value of water resources for economic development versus environmental sustainability in Australia from 1843 to 2011, Global Environ. Change, 42, 82-92, 2017.

Wei, J., Wei, Y., Tian, F., Nott, N., de Witt, C., Guo, L., and Lu, Y.: An Analysis of Conflict and Cooperation Dynamics over Water Events in the Lancang-Mekong River Basin, Hydrol. Earth Syst. Sci. Discuss. [preprint], https://doi.org/10.5194/hess-2020390, in review, 2020.

WLE: CGIAR Research Program on Water, Land and Ecosystems Greater Mekong: Dataset on the Dams of the Irrawaddy, Mekong, Red and Salween River Basins, Vientiane, Lao PDR, available at: https://wle-mekong.cgiar.org/maps/ (last acces: 7 April 2021), 2018.

Wolf, A. T., Natharius, J. A., Danielson, J. J., Ward, B. S., and Pender, J. K.: International River Basins of the World, Int. J. Water Resour. Dev., 15, 387-427, https://doi.org/10.1080/07900629948682, 1999.
You, Z., Feng, Z., Jiang, L., and Yang, Y.: Population Distribution and Its Spatial Relationship with Terrain Elements in LancangMekong River Basin, Mount. Res., 032, 21-29, 2014.

Yu, Y., Tang, P., Zhao, J., Liu, B., and Mclaughlin, D.: Evolutionary cooperation in transboundary river basins, Water Resour. Res., 55, 9977-9994, https://doi.org/10.1029/2019WR025608, 2019a.

Yu, Y., Zhao, J., Li, D., and Wang, Z.: Effects of Hydrologic Conditions and Reservoir Operation on Transboundary Cooperation in the Lancang-Mekong River Basin, J. Water Resour. Plan. Manage., 145, 04019020, https://doi.org/10.1061/(ASCE)WR.19435452.0001075, 2019b.

Zeitoun, M. and Mirumachi, N.: Transboundary water interaction I: reconsidering conflict and cooperation, Int. Environ. Agreem.: Polit. Law Econ., 8, 297-316, https://doi.org/10.1007/s10784008-9083-5, 2008.

Zeitoun, M., Mirumachi, N., and Warner, J.: Transboundary water interaction II: the influence of 'soft' power, Int. Environ. Agreem.: Polit. Law Econ., 11, 159-178, https://doi.org/10.1007/s10784-010-9134-6, 2011. 